V. Beumer et al.

\title{
Biogeochemical plant site conditions in stream valleys after winter flooding: a phytometer approach
}

V. Beumer ${ }^{1,2}$, J. N. Ohm ${ }^{1}$, G. van Wirdum ${ }^{2}$, B. Beltman ${ }^{1}$, J. Griffioen ${ }^{2}$, and J. T. A. Verhoeven ${ }^{1}$

${ }^{1}$ Utrecht University, Institute of Environmental Biology, Landscape Ecology group, Utrecht, The Netherlands

${ }^{2}$ Deltares/TNO Built Environment and Geosciences, Subsurface and Groundwater Systems group, Utrecht, The Netherlands

Received: 30 October 2008 - Accepted: 14 November 2008 - Published: 23 December 2008 Correspondence to: V. Beumer (victor.beumer@deltares.nl)

Published by Copernicus Publications on behalf of the European Geosciences Union.

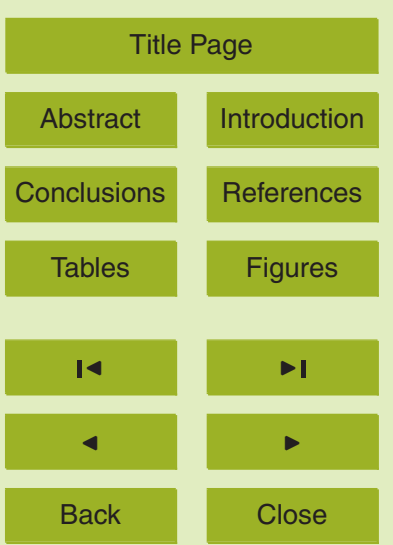

Full Screen / Esc

Printer-friendly Version

Interactive Discussion 


\section{Abstract}

Reintroduction of winter flooding events will have strong effects on the plant growth conditions in the parts of stream valleys that have not been accustomed to flooding in recent years. The major goal of this research is, firstly, to investigate the plant growth conditions in floodplain soils in the period after a winter flood and, secondly, to assess whether a phytometer setup is suitable for the evaluation of winter flooding on plant growth conditions. Soil cores of three agricultural and three semi-natural grassland sites have been exposed to a simulated winter flooding event. Then, cores were subjected to spring conditions in a growth chamber and were planted with seedlings of 10 Anthoxantum odoratum and Lythrum salicaria. The growth conditions changed in opposite directions for our two phytometer species, expressed as biomass and nutrient changes. We discuss possible causes of an increase or decrease in biomass, such as (1) soil nutrient effects ( $\mathrm{N}, \mathrm{P}$ and $\mathrm{K}$ ), (2) toxic effects of $\mathrm{NH}_{4}, \mathrm{Fe}$ and $\mathrm{Al}$, and (3) possible shortage of other macro- and micronutrients. The conclusions are that plant growth 15 after winter flooding was affected by enhanced nutrient and toxicant availabilities in agricultural sites and mainly by soil nutrients in the semi-natural sites. The use of the two species selected had clear advantages: Lythrum salicaria is well-suited to assess the nutrient status in previously flooded soils, because it is a well-known invader of wetlands and not easily hampered by potentially toxic compounds, while $A$. odoratum is less frequently found at wetland soils and more sensitive to toxic compounds and, therefore, a better indicator of possible toxic effects as a result of winter flooding than L. salicaria.

\section{Introduction}

Global climate change has shown to lead to a warming trend and more extreme rainfall and droughts in North-Western Europe. As a result, flooding and flood damage from rivers and streams are becoming more frequent and severe, especially in winter. Water
BGD

$5,5203-5232,2008$

\section{Plant site conditions} after winter flooding

V. Beumer et al.

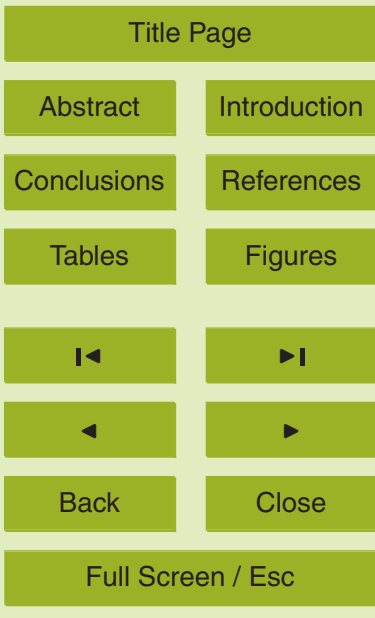

Printer-friendly Version

Interactive Discussion 
management strategies are being developed in The Netherlands to counteract this problem. In periods with high rainfall and resulting high river discharge, floodwater is diverted to areas where it is less harmful. Many of these areas are targeted for nature conservation and effects of the flooding on plant growth conditions must be considered.

5 Reintroduction of winter flooding events will have strong effects on the plant growth conditions in the parts of the stream valleys that have not been accustomed to flooding in recent years (Lamers et al., 2006; Hogan et al., 2004). The present land uses of these floodplains include agricultural use for live stock raising and semi-natural use (extensive grazing, haymaking) for conservation of grassland biota. These different 10 land uses have resulted in soils with different biogeochemical characteristics.

During a flood event, a soil becomes anaerobic and its ammonium concentration $\left(\mathrm{NH}_{4}\right)$ will increase, due to a net increase of ammonification and strong reduction of (aerobic) nitrification processes. Denitrification of $\mathrm{NO}_{3}$ present will cause gaseous nitrogen loss to the atmosphere $\left(\mathrm{N}_{2} \mathrm{O}\right.$ and $\mathrm{N}_{2}$; Reddy and Patrick Jr., 1984). After the

flood has receded, the penetration of air causes soil oxidation, so that $\mathrm{NH}_{4}$ will be nitrified to $\mathrm{NO}_{3}$. Flooding also leads to the reduction of $\mathrm{Fe}(\mathrm{III})$-oxides to $\mathrm{Fe}(\mathrm{II})$, followed by oxidation back to $\mathrm{Fe}$ (III)-oxides as soon as the flood has receded. The oxidised form of Fe has a stronger binding capacity of phosphate $\left(\mathrm{PO}_{4}^{3-}\right)$ than $\mathrm{Fe}(\mathrm{II})$. Flooding, therefore, causes a net increase in $\mathrm{P}$ availability in the floodplain soil (Darke and Walbridge, 2000). Although the process is reversible in case of reoxidation, Fe-sulphides are insoluble and will precipitate to FeS or pyrite $\left(\mathrm{FeS}_{2}\right)$ during the period of flooding and sulphate reduction. Less $\mathrm{Fe}(\mathrm{III})$ is available to bind $\mathrm{PO}_{4}$ after recession of the flood, because oxidation of pyrite is slow (Roden and Edmonds, 1997). The effects of flooding on soil potassium have hardly been investigated and the few studies carried out in wetlands have described contrasting effects (Olde Venterink, 2002). Nutrient availability, primarily of nitrogen, phosphorus and potassium, is a major factor determining biomass and species composition of herbaceous vegetation. Other macronutrients as $\mathrm{Ca}, \mathrm{Na}$, $\mathrm{Mg}$ and $\mathrm{SO}_{4}$ can be affected by winter flooding as well through reduction/oxidation-, cation exchange and complexation processes.

BGD

5, 5203-5232, 2008

Plant site conditions after winter flooding

V. Beumer et al.

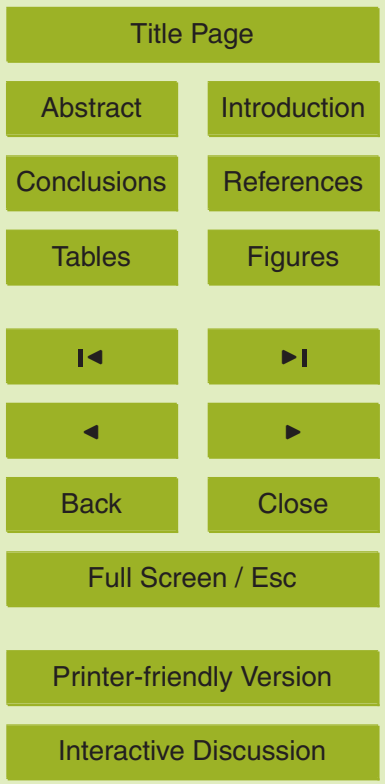

5205 
Biogeochemical soil processes related to flood-dry cycles may also produce phytotoxines with strong effects on the vegetation. During a flood event soil aeration will decrease; micro-organisms active in organic matter breakdown will start to use electron acceptors alternative to oxygen and will subsequently shift to $\mathrm{NO}_{3}, \mathrm{Fe}(\mathrm{III})$ and sulphate $5\left(\mathrm{SO}_{4}\right)$, thereby producing $\mathrm{Fe}(\mathrm{II})$ and sulphides $\left(\mathrm{S}^{2-}, \mathrm{HS}^{-}\right.$and $\left.\mathrm{H}_{2} \mathrm{~S}\right)$ (Ponnamperuma, 1972). Changes in $\mathrm{pH}$ associated with flooding events may also cause a release of $\mathrm{Fe}$ and $\mathrm{Al}$ ions. Hence, flooding events can lead to an increase of $\mathrm{Fe}(\mathrm{II}), \mathrm{Al}(\mathrm{III}), \mathrm{NH}_{4}$ and sulphides, which are all potentially toxic for plants (Mitsch and Gosselink, 1993). However, after a flooding period, potentially toxic elements will be reoxidised into compounds which are relatively harmless, and sometimes even essential, to plants.

The occurrence of winter floods implies that effects occur outside the growing season, when plants are dormant or in a quiescent state. These effects of winter flooding are probably not acting directly on the plants during the event itself, but more by biogeochemical consequences of flooding for plant soil conditions, which may last into 15 the growing season, after the flood has receded and the soil becomes aerated again. To our knowledge it has not been studied to what extent such alterations affect plant growth conditions. Do effects of a winter flood event, indeed, impact the plant growth afterwards or will the effects disappear shortly after re-aeration? A suitable method to assess plant growth conditions is the use of phytometers (test plants) on soil cores 20

or pots in an experimental setup (Wheeler et al., 1992). The phytometer approach enables evaluation of the consequences of flooding via the soil conditions on plant growth while geochemical measurements only address individual parameters. Soil or pore water measurements might indicate changes in nutrient availability; however, they do not reveal the plant response to it. High nutrient availability might be the result of hampered plant growth and associated nutrient uptake. With only geochemical information it would be more difficult to evaluate the effects on plants, because nutrients and toxic substances have opposite effects and might also interfere with one another. Phytometers can indicate a potential nutrient shortage with their internal nutrient ratios (Koerselman and Meuleman, 1996) that cannot be concluded from soil properties

\section{BGD}

5, 5203-5232, 2008

\section{Plant site conditions} after winter flooding

V. Beumer et al.

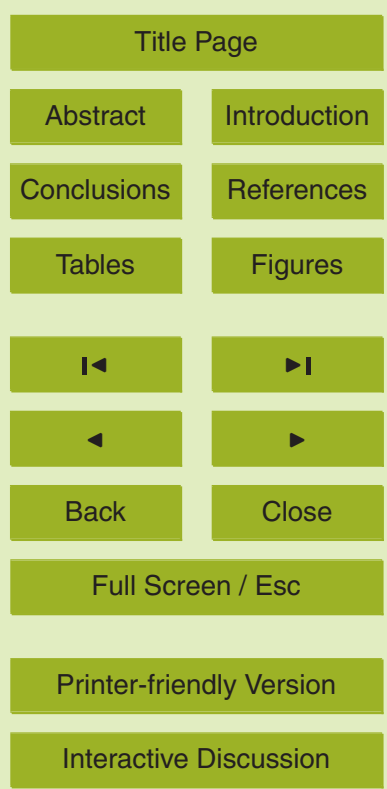

Interactive Discussion 
alone. However, species may differ strongly in their reactions to a certain set of plant site conditions and such specific effects have to be taken into account. The use of more than one species will reveal some of the possible differences. We have selected two species as phytometers on the basis of their growth potential and their occurrence 5 in the floodplain environment: Anthoxantum odoratum L. (Sweet vernal grass) and Lythrum salicaria L. (Purple loosestrife).

The major goal of this research is, firstly, to investigate the plant growth conditions in floodplain soils in the period after a winter flood and, secondly, to determine whether a phytometer setup is suitable for the evaluation of winter flooding on plant growth condi10 tions. We have raised the following research questions: (1) How does winter flooding in riverine grasslands affect the biogeochemical plant growth conditions in spring? (2) How does land use (agricultural versus semi-natural) influence these effects? (3) What do plant nutrient concentrations and their stoichiometry indicate about the changes of plant growth conditions? (4) Can the responses of seedlings of floodplain species 15 ("phytometers") be used in evaluations of the consequences of flooding for the vegetation? And, (5) do the two selected species show different responses and what does that imply for the interpretation of effects at the plant community level?

We hypothesize that the use of phytometers will reveal geochemical changes after a winter flooding event. At sites with $P$ limited plant growth, the limitation will be lifted after winter flooding due to phosphate mobilization processes during soil anoxia resulting in increased $\mathrm{P}$ uptake by the phytometers. Due to a net increase of ammonification during the winter flood event soil ammonium concentration will be elevated and might reach toxic levels, negatively influencing plant growth. The phytometers will reflect such effects through lower survival or hampered growth. The toxic effects of Fe and Al will 25 be species specific as well.

To test our hypotheses we have set up a phytometer experiment. Soil cores from floodplain soils with different land uses have been exposed to a simulated winter flooding event. Then, cores were subjected to spring conditions in a growth chamber and were planted with seedlings of Anthoxantum odoratum and Lythrum salicaria. These

BGD

5, 5203-5232, 2008

\section{Plant site conditions} after winter flooding

V. Beumer et al.

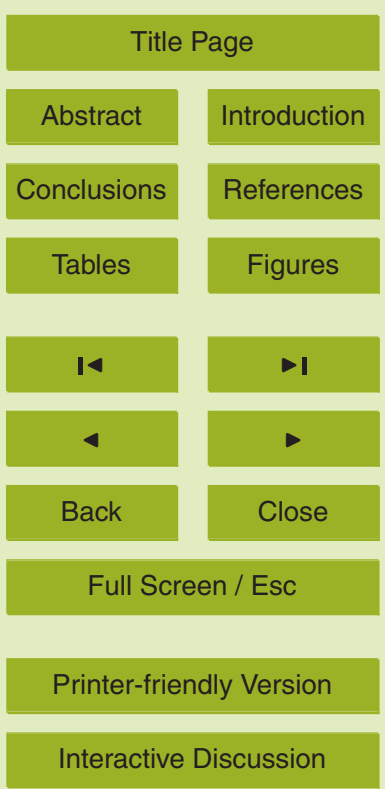

Interactive Discussion 
species together might reveal whether effects are of nutritious or toxic nature, because they have contrasting preferences for hydrological and associated geochemical conditions: L. salicaria prefers wet, eutrophic, conditions and A. odoratum drier, mesotrophic, conditions.

\section{Materials and methods}

Intact soil cores in PVC tubes collected in the field (see below) were subjected to a 2month flooding treatment in a dark room with constant temperature $\left(15^{\circ} \mathrm{C}\right)$. The cores were subsequently drained, planted with phytometers and kept in a plant growth chamber. Two plant species were used as phytometers: the grass Anthoxanthum odoratum dance in river catchments, germination and seedling transplantation success, but not because of their tolerance to flooded conditions. A. odoratum is known to be sensitive to flooding and, therefore, less abundant in regularly flooded grasslands. In the field the species is absent in permanently wet or very dry sites and prefers slightly acid soils available $\mathrm{PO}_{4}$ can reduce these effects (Davies and Snaydon, 1973), possibly by complexation of $\mathrm{Al}$ and $\mathrm{PO}_{4}$ (Darke and Walbridge, 2000). In the field L. salicaria prefers moist to very wet, eutrophic sites and can sustain long and highly frequent flooding during the growing season (Weeda et al., 1987). In spring it primarily reproduces via seed anaerobic soil conditions as a seedling.

The soils were collected in August 2006 on the floodplains of the Beerze river (province of Noord-Brabant, The Netherlands) from six grassland sites that have not been flooded by the river in the last decade. The sites are divided into two groups based on their present or previous land use: (1) semi-natural grassland without intensive agricultural history (SNI=Semi-Natural I, SNII=Semi-Natural II and ASN=Acidic Semi-Natural) and (2) actual or previous agricultural grassland (FA=Former Agricul-

BGD

$5,5203-5232,2008$

\section{Plant site conditions} after winter flooding

V. Beumer et al.

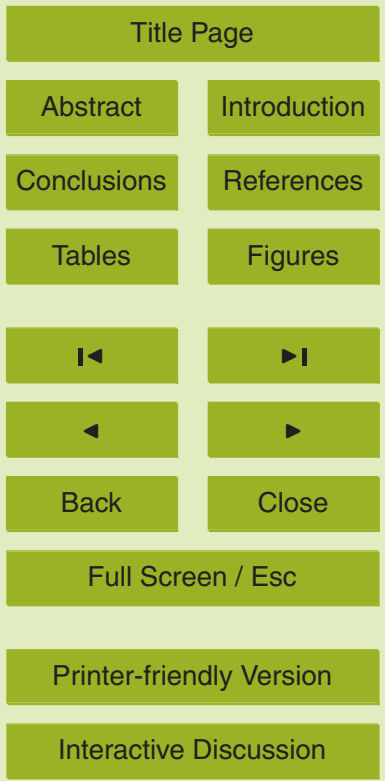

Interactive Discussion 
tural now semi-natural, Al=Agricultural I and All=Agricultural II). These differences in land use history have resulted in differences in soil nutrient contents and vegetation (Table 1). The floodplains have sandy soils and generally are discharge areas of calcium-rich groundwater. One semi-natural site (ASN) had a low pore water $\mathrm{pH}$ of 5 3.8-3.9 units. The FA site is placed in the group of agricultural land use, despite its present semi-natural land use, because of its former agricultural use and associated fertilizer application. None of the sites had been flooded in the winter previous to our experiment.

In all sites studied, 32 cores were collected to enable a winter-flooded and a control 10 treatment, with separate groups of cores for the two phytometer species: 6 sites $\times 2$ treatments $\times 2$ plant species gives 24 groups with $n=8$. Intact soil cores were collected in PVC-tubes $(\varnothing: 8 \mathrm{~cm}$ and length: $30 \mathrm{~cm})$. The winter-flooded treatment was performed by subjecting the cores to flooding with artificial brook water $\left(\mathrm{SO}_{4}=49.0\right.$, $\mathrm{NO}_{3}=10.2, \mathrm{NH}_{4}=1.6, \mathrm{PO}_{4}=0.05, \mathrm{~K}=14.9, \mathrm{Fe}=0.2$, all as $\mathrm{mg} \cdot \mathrm{I}^{-1}$, and $\mathrm{pH}=6.8$ ) that was 15 refreshed every two weeks. The control cores were kept in a drained condition, but desiccation was prevented by regularly adding small amounts of rain water. All cores were stored in darkness at a temperature of $15^{\circ} \mathrm{C}$. After 8 weeks of winter flooding, all cores were transported to a plant growth chamber (with a temperature of $20^{\circ} \mathrm{C}$, air humidity of $75 \%$ and a light period with a photon flux density of 400 micromols $^{-1} \mathrm{~m}^{-2}$ 20 from 07:00 till 21:30) to simulate spring conditions after the flood has receded. The cores were perforated at the bottom and placed in artificial groundwater $\left(\mathrm{SO}_{4}=18.6\right.$, $\mathrm{NO}_{3}=0.04, \mathrm{NH}_{4}=0.2, \mathrm{PO}_{4}=0.18, \mathrm{~K}=6.7, \mathrm{Fe}=0.03$, all as $\mathrm{mg} \cdot \mathrm{l}^{-1}$, and $\mathrm{pH}=8.0$ ) up to $10 \mathrm{~cm}$ below soil surface so the groundwater could infiltrate from bottom to top. The artificial groundwater was refreshed every two weeks. Rain water was supplied regularly 25 at the top.

One week after seed germination, equally sized seedlings of the phytometer species were planted on the cores. Survival was monitored and after 8 weeks the aboveground biomass was harvested, dried for $48 \mathrm{~h}$ at $70^{\circ} \mathrm{C}$ and weighed. After grinding, the plant material was digested with a mixture of salicylic acid $(0.36 \mathrm{M})$ and sulphuric acid

BGD

5, 5203-5232, 2008

\section{Plant site conditions} after winter flooding

V. Beumer et al.

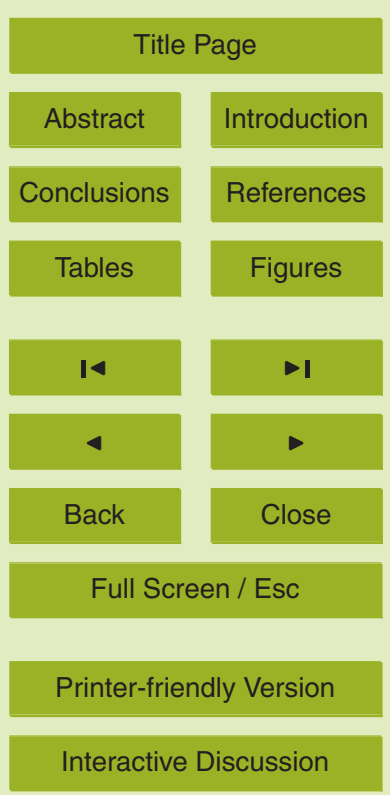


(29.5 M) using a selenium mixture as catalyst (Page et al., 1982). Nitrogen, $\mathrm{P}$ and $\mathrm{K}$ concentrations were determined colorimetrically on a continuous flow analyzer (SA-40; Skalar analytical, Breda, the Netherlands). The same extraction method was used to determine the soil nutrient contents; it mainly concerns the organic and exchangeable 5 fractions of $\mathrm{N}, \mathrm{P}$ and $\mathrm{K}$ in the soil.

The nutrient concentrations of the plants were used as an indication for nutrient limitation. The N:P ratios higher than 15 indicate $P$ limitation and lower than 14 indicate $N$ limitation, $\mathrm{N}: \mathrm{K}$ ratios higher or lower than 2.1 indicate $\mathrm{K}$ limitation and $\mathrm{N}$ limitation, respectively, and $\mathrm{P}: \mathrm{K}$ ratios higher or lower than 0.3 indicate $\mathrm{K}$ limitation and $\mathrm{P}$ limitation, respectively (Koerselman and Meuleman, 1996; Olde Venterink et al., 2003).

Pore water from 4 cores per treatment group was sampled using soil moisture samplers (Rhizon SMS-10 cm; Eijkelkamp Agrisearch Equipment, Giesbeek, the Netherlands). Due to logistic reasons we had to limit the replication of the soil moisture measurements to four. Therefore, we considered the cores with $L$. salicaria and $A$. odoratum equal in this and sampled two replicate cores of both species. After the $\mathrm{pH}$ was determined, pore water samples were stored at $-20^{\circ} \mathrm{C}$. Concentrations of $\mathrm{NH}_{4}, \mathrm{NO}_{3}$, $\mathrm{PO}_{4}, \mathrm{~K}, \mathrm{Al}, \mathrm{Fe}, \mathrm{Cl}, \mathrm{SO}_{4}, \mathrm{Mg}$ and $\mathrm{Na}$ were determined colorimetrically on a continuous flow analyzer.

Data were tested for normal distribution and transformed with natural logarithm if needed. One-way and two-way ANOVA were used to investigate the data sets. To test differences in plant variables between the areas within the land uses, the sites were analysed as nested factors within the land use factor in a two-way ANOVA. All statistical analyses were performed using SPSS 15.0.1 for Windows.

\section{BGD}

$5,5203-5232,2008$

\section{Plant site conditions after winter flooding}

V. Beumer et al.

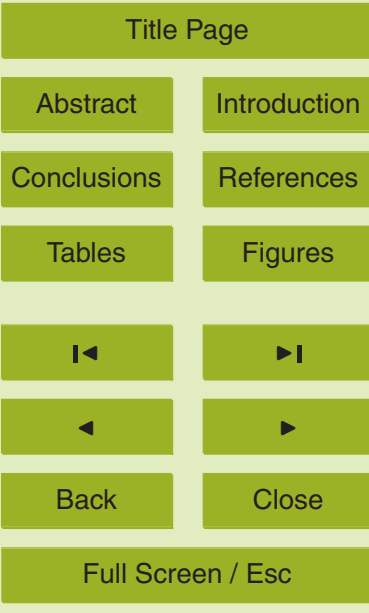

Printer-friendly Version

Interactive Discussion 


\section{Results}

\subsection{Site characterization}

Table 1 presents some characteristics of the sites we used. The soils of the SNI and SNII sites had the highest $\mathrm{N}$ and organic matter content and the soils of the Al and All 5 sites had the lowest. The sites of the agricultural land use group had the highest soil $\mathrm{P}$; probably as a result of fertilizer applications. The nutrient ratios in plant biomass in these sites indicated a clear $\mathrm{K}$ and $\mathrm{N}$-limitation, reflecting the strong accumulation of bio-available P in the soils. In the vegetation of the SNI and SNII sites, plant nutrient ratios revealed a $\mathrm{N}$ limitation, but, here, something else than availability must be hampering the $\mathrm{N}$ uptake of the vegetation, since bio-available $\mathrm{N}$ is present in higher concentrations than in the other sites. The ASN site has a co-limitation of $\mathrm{N}$ and $\mathrm{K}$ which explained the higher bio-available $\mathrm{P}$ in the soil than in the SNI and SNII sites.

\subsection{Phytometer biomass and survival}

Table 2 shows that the survival of both species on the cores from semi-natural sites which had received the winter flooding treatment was higher than on the control cores. For $L$. salicaria this was especially the case for the cores from the ASN site. Flooding treatment had almost no effect on phytometer survival in the soils from the agricultural sites.

The effect of winter flooding on phytometer biomass was opposite for the two species 20 (Fig. 1). A two-way ANOVA for each species with treatment and land use as fixed factors, and site as a nested factor within the land use factor, indicated no interaction effects for both species (Table 3). Treatment turned out to significantly affect the biomass of $A$. odoratum: the biomass was lower in the winter-flooded treatment than in the control treatment (on average 38\% lower); regardless of the difference in land use (Table 3). Figure 1 showed this difference primarily for the ASN, Al and All cores. For L. salicaria a significant treatment effect was found as well: the biomass was higher in

\section{Plant site conditions after winter flooding}

V. Beumer et al.

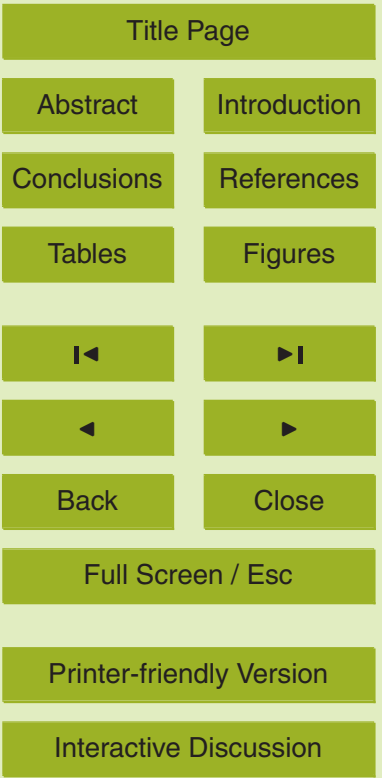


the winter-flooded treatment. This overall effect was mostly the result of the cores of the agricultural land use group. For both species a significant land use effect was found (Table 3), i.e., they had a significantly lower biomass on the semi-natural cores than on the agricultural ones. The analysis of site as a nested factor within land use indicated that there was no significant difference in $L$. salicaria biomass between the cores of different agricultural sites (Table 3). Among the cores from semi-natural sites, the biomass on the SNII cores was significantly lower than on the cores from the other two sites. Anthoxantum odoratum biomass differed significantly between the semi-natural cores as well as between the agricultural cores. It was highest in the control cores and showed the largest reduction in the flooding-treated cores from the ASN site (Fig. 1).

Using one-way ANOVA for both land uses separately for each species and with treatment as a fixed factor, we investigated effects of the winter-flooded treatment per land use per species (indicated at the top of the graphs in Fig. 1). We found a significant, negative effect of the winter-flooded treatment on the biomass of $A$. odoratum on the 15 semi-natural cores $(F=5.0$ and $p<0.05)$, and this effect was not significant on the agricultural cores. The biomass of $L$. salicaria was significantly positively affected by winter flooding on the agricultural cores $(F=7.9$ and $p<0.01)$, and not on the semi-natural cores.

\subsection{Phytometer nutrients and nutrient stoichiometry}

\subsubsection{Anthoxantum odoratum}

Figure 2 shows the nutrient concentrations (N, P and K) of $A$. odoratum and Table 3 presents the results of a two-way ANOVA with treatment and land use as fixed factors, and site nested within land use for both phytometer species separately. We did not find a significant treatment effect, but we did find a land use effect: the $A$. odoratum

$\mathrm{N}$ concentrations were significantly higher on the semi-natural than on the agricultural cores. The nested site factor indicated that the cores of the sites within both land use groups differed significantly (Table 3 ). Total $\mathrm{N}$ content (TN) of the phytometers, how-

\section{BGD}

$5,5203-5232,2008$

\section{Plant site conditions} after winter flooding

V. Beumer et al.

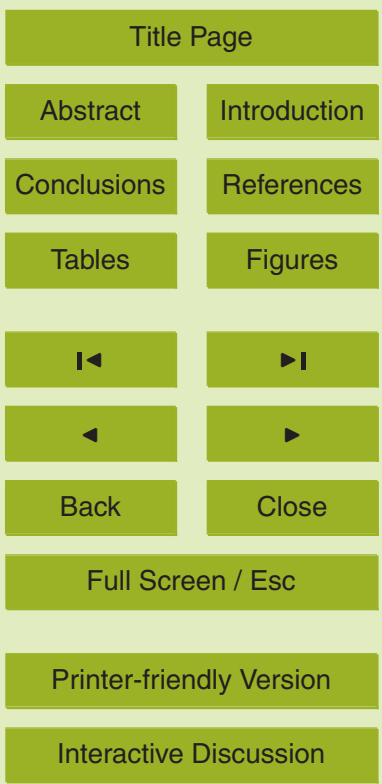


ever, was significantly affected by both treatment and land use (Table 3). TN was lower in the winter-flooded treatment than in the control (Fig. 2d) and cores of the sites differed significantly within both land use groups (Table 3). The treatment effect on TN concurs with that on the biomass (note that TN is the phytometer $\mathrm{N}$ concentration mul5 tiplied by its biomass). We found significant interaction effects between the two main factors for the phytometers $\mathrm{P}$ as well as $\mathrm{K}$ concentrations, implying that the two land use groups showed different treatment effects. Phosphor concentrations on the seminatural cores were mostly higher in the winter-flooded treatment than in the control, while on the agricultural cores they were generally lower than in the control (Fig. 3b). 10 The $\mathrm{K}$ concentrations on the cores of both land use groups were generally higher in the winter-flooded treatment than in the control, however, the difference was larger on the semi-natural cores (Fig. 2c; $116 \%$ versus 33\% increase). Note that the cores differed significantly within the land use groups (Table 3 ) and that the $\mathrm{K}$ concentrations of $A$. odoratum increased due to the winter flooding effect (Fig. 2c), while their biomass 15 decreased. The treatment and land use effect on TP were similar to the effects on the biomass. However, for TK this was not the case: TK was not affected significantly by treatment (Table 3).

\subsubsection{Lythrum salicaria}

Figure 3 shows the nutrient concentrations $(N, P$ and $K)$ of $L$. salicaria. There were 20 no significant differences in phytometer $\mathrm{N}$ concentrations between treatments or land use groups; however, cores differed significantly within both land use groups (Table 3). Phytometer TN was significantly affected by land use and treatment (Table 3) concurrently to its biomass. Land use had a significant effect on both phytometer $P$ and $K$ concentration (Table 3); $\mathrm{P}$ concentration was higher and $\mathrm{K}$ concentration lower than on the cores with agricultural than with semi-natural land use (Fig. $3 b$ and $3 c$ ). Both TP and TK were significantly affected by land use as well as treatment (Table 3), with higher values on the agricultural than on the semi-natural land use and higher values in winter-flooded than in control treatments (Fig. 3e and f). None of the nutrients showed 5213

\section{BGD}

5, 5203-5232, 2008

\section{Plant site conditions after winter flooding}

V. Beumer et al.

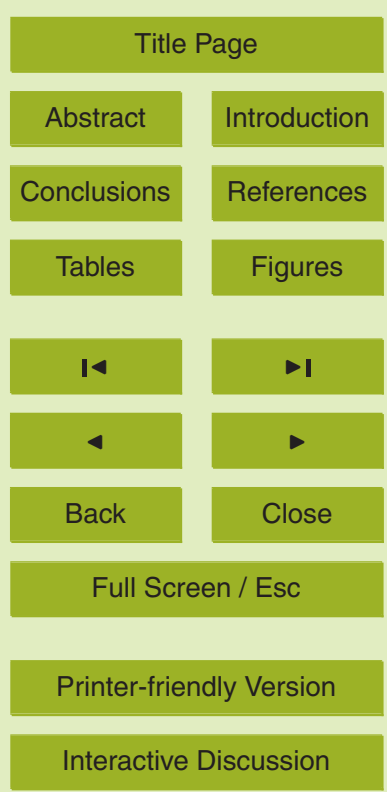


interactions among treatment and land use. However, L. salicaria took up more N, P and $\mathrm{K}$ from the agricultural soil cores and more $\mathrm{P}$ and $\mathrm{K}$ from the cores that had been subjected to winter flooding. One-way ANOVA with treatment as a fixed factor, using only the cores with agricultural land use, showed significant increases of all three total 5 nutrient contents when cores were winter-flooded (Fig. $3 d$, e and f; TN: $F=9.9$ and $p<0.01$; TP: $F=12.6$ and $p<0.01$; TK: $F=12.6$ and $p<0.01)$.

To compare the $\mathrm{N}, \mathrm{P}$ and $\mathrm{K}$ uptake between the two phytometer species (TN, TP and TP), we have used two-way ANOVA for both land use groups separately, with treatment and species as fixed factors. Note that these results are not presented in a 10 table. In the semi-natural cores we found a significant interaction effect for TN $(F=4.4$ and $p<0.05)$. On average, $A$. odoratum took up $45 \%$ less $N$ from the winter-flooded than from the control cores, while $L$. salicaria extracted $17 \%$ more $\mathrm{N}$ from the soil in the winter-flooded cores. In the cores from agricultural soils all three total phytometer nutrient contents had significant interaction effects (TN: $F=8.3$ and $p<0.01$; TP: $F=9.3$ 15 and $p<0.01$; TK: $F=5.9$ and $p<0.05)$. Lythrum salicaria took up more of all three nutrients in the winter-flooded than in the control treatment (ranging between $51-71 \%$ more), whereas $A$. odoratum extracted more of all three nutrients in the control than in the winter-flooded treatment (ranging between $41-74 \%$ more).

\subsubsection{Nutrient stoichiometry}

20 The nutrient ratios of $A$. odoratum in the control treatment indicated $\mathrm{P}$ limitation in the SNI and SNII cores, $\mathrm{K}$ limitation in the ASN cores and N limitation in the AI, All and FA cores (Fig. 4a, $b$ and $c$ ). Treatment affected N:P, N:K and P:K ratios significantly for this phytometer (Table 3 ). In general, all ratios decreased when cores were winter-flooded (Fig. $4 \mathrm{a}, \mathrm{b}$ and $\mathrm{c}$ ). This indicates that $A$. odoratum experienced a shift towards stronger $25 \mathrm{~N}$ limitation in most cores. On the SNII cores we found $\mathrm{P}$ limitation remaining in the winter-flooded treatment. On the ASN cores both $\mathrm{N}: \mathrm{K}$ and $\mathrm{P}: \mathrm{K}$ ratios showed a shift from indication of $\mathrm{K}$ limitation to indication of $\mathrm{N}$ limitation.

The nutrient ratios of $L$. salicaria in the control treatment indicated weak $P$ limitation

BGD

$5,5203-5232,2008$

\section{Plant site conditions after winter flooding}

V. Beumer et al.

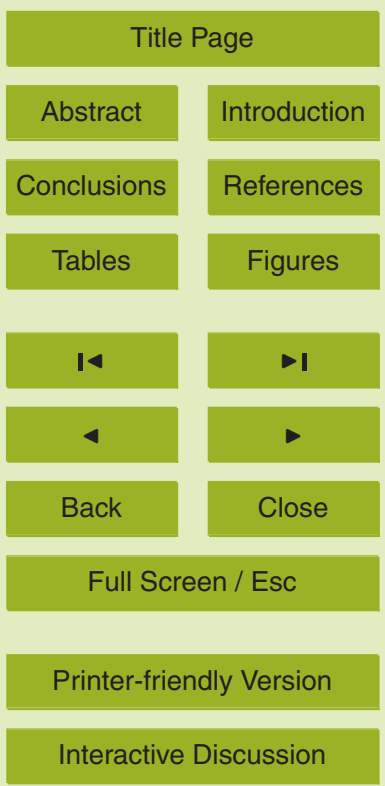

Interactive Discussion 
on the SNI cores, $\mathrm{N}$ limitation on the SNII, ASN, Al and All cores and $\mathrm{K}$ limitation on the FA cores (Fig. 4d, e and f). The winter-flooded treatment affected N:K and P:K ratios of $L$. salicaria significantly (Table 3 ). Especially on the SNI and the FA cores ratios decreased when cores had been winter-flooded, indicating a weaker $\mathrm{K}$ limitation 5 on FA cores and a change from indication of $\mathrm{P}$ limitation to $\mathrm{N}$ and $\mathrm{P}$ co-limitation on SNI cores.

\subsection{Pore water chemistry}

Two-way ANOVA with treatment and land use as fixed factors for pore water nutrients measured 3 days after the start of the phytometer experiment showed significant treatment effects for $\mathrm{NO}_{3}$ and $\mathrm{NH}_{4}$ and a significant land use effect for $\mathrm{PO}_{4}$ (Table 4). Pore water $\mathrm{NH}_{4}$ was significantly higher and $\mathrm{NO}_{3}$ significantly lower (except in SNI and SNII cores) in the winter-flooded than in the control cores (Table 4). Two-way ANOVA with time and treatment as fixed factors, for both land use groups separately, showed: a significant time effect for $\mathrm{PO}_{4}$ in the semi-natural land use cores, and significant interactions of time and treatment for $\mathrm{NO}_{3}$ in the agricultural land use cores as well as for $\mathrm{NH}_{4}$ in the cores of both land use groups (Table 4). Phosphate decreased significantly over time in the semi-natural group, but showed no trend in the agricultural group. Pore water nitrate decreased significantly over time in the control treatment, whereas it did not show a trend in the winter flooding treatment (except in the SNII cores). For $\mathrm{NH}_{4}$ it in the SNI cores) and no trend in the control.

Pore water $\mathrm{pH}$ increased significantly during the winter flooding treatment in cores from semi-natural land use sites (data not shown). At the start of the experiment $\mathrm{pH}$ was mostly higher in the cores from sites with agricultural than with semi-natural land

\section{BGD}

5, 5203-5232, 2008

\section{Plant site conditions after winter flooding}

V. Beumer et al.

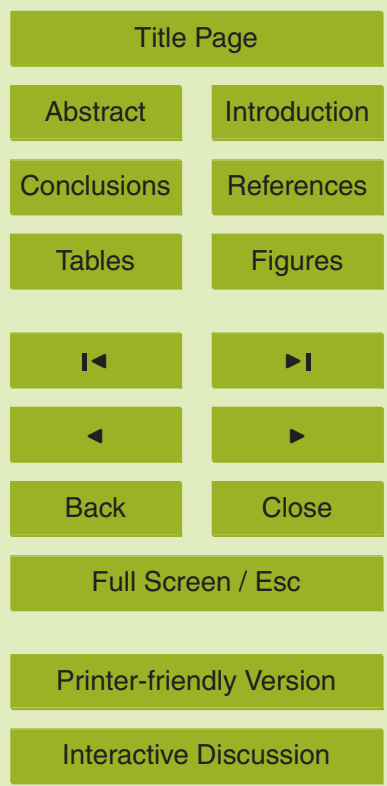
$\mathrm{SNI}, \mathrm{SNII}, \mathrm{FA}$ and Al cores. Pore water $\mathrm{pH}$ in the ASN cores with control treatment was low and $\mathrm{Al}$ was high. Pore water Fe showed significant treatment effects in the cores of both land use groups. The Fe concentrations were higher in the winter-flooded 
than in the control cores, albeit that measurements in the SNI and SNII cores were incomplete. Pore water Fe increased during winter flooding (data not shown) and, subsequently, showed significant treatment effects at the start of the phytometer growth (Table 5). Pore water $\mathrm{Ca}$ did not show significant treatment effects in the cores of both

5 land use groups; however, Ca concentration in the flooded cores at the start of the phytometer growth was three times as high as in the control cores (Table 5). Pore water concentrations of $\mathrm{Na}, \mathrm{Mg}$ and $\mathrm{SO}_{4}$ were also not significantly different between the treatments (data not shown). Sulphate reduction did take place in some cores during the flooding treatment; however, it seemed that the sulphides were oxidised 10 again at day 3 of the phytometer growth.

\section{Discussion and conclusion}

In this study, we wanted to test a phytometer approach to evaluate whether plant growth conditions in spring were affected by a preceding winter flood, even after the flood had receded. The flooding treatment resulted in changed growth conditions affecting 15 our two phytometer species in opposite directions. For L. salicaria, conditions were generally improved in the winter-flooded treatment, while for $A$. odoratum they had declined. This surprising result shows that the ecological characteristics of species occurring in flooded sites may differ quite strongly. Possible causes of an increase or decrease in biomass as a result of a previous winter flooding might include (1) soil nutrient effects ( $\mathrm{N}, \mathrm{P}$ and $\mathrm{K}$ ), (2) toxic effects of $\mathrm{NH}_{4}, \mathrm{Fe}$ and $\mathrm{Al}$, and (3) possible shortage of other macro- and micronutrients. However, our results have shown that this last possibility most probably did not play a role in our experiment.

\subsection{N, P and K effects}

A decrease in biomass growth after winter flooding suggests that the limiting nutrient in the control situation became more limiting as a result of the flooding or that another

\section{BGD}

$5,5203-5232,2008$

\section{Plant site conditions after winter flooding}

V. Beumer et al.

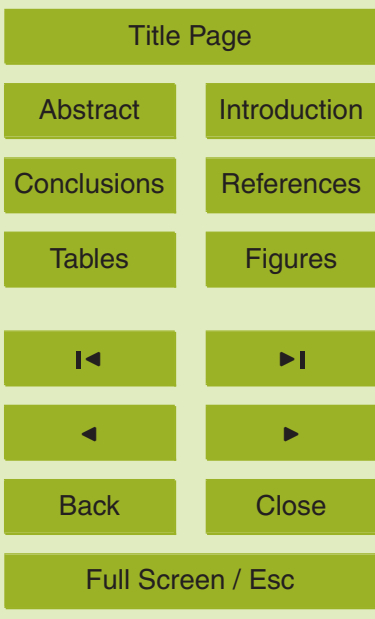

Printer-friendly Version

Interactive Discussion 
nutrient started to overrule the original limitation by being even more limiting. In the ASN site, where the lower biomass of $A$. odoratum in the winter-flooded treatment was obvious, the $\mathrm{K}$ limitation in the control cores changed into $\mathrm{N}$ limitation in the winterflooded cores. The (non-flooded) vegetation in the field indicated an $\mathrm{N}$ and $\mathrm{K}$ co5 limitation. These results imply that when winter flooding will be introduced here, $\mathrm{K}$ might no longer limit plant growth at this site. Although the $\mathrm{N}$ uptake by $A$. odoratum was strongly reduced after winter flooding, it is hard to tell whether the $\mathrm{N}$ limitation was more severe than the original $\mathrm{K}$ limitation. In the SNI and SNII sites, A. odoratum indicated $\mathrm{P}$ limitation in both the control and winter-flooded treatments, whereas the 10 vegetation in the field indicated $\mathrm{N}$ limitation. The phytometers produced only a little less biomass in the winter-flooded than in the control treatment and were able to maintain their $\mathrm{P}$ uptake, suggesting that $\mathrm{P}$ limitation was not the primary cause of the lower biomass production. Similarly, in the $\mathrm{Al}$ and All sites $A$. odoratum growth was $\mathrm{N}$ limited in both treatments, but there are no indications that the slightly lower growth in winter15 flooded soils was due to a stronger $\mathrm{N}$ limitation. Concluding, winter flooding did not affect $A$. odoratum biomass production strongly, but when it did the biomass decreased, and limiting nutrients did not correspond with the non-flooded field situation.

Lythrum salicaria reacted differently. It showed a higher biomass after winter-flooding in the agricultural sites, which suggests a higher availability of the limiting nutrient. Nutrient stoichiometry in the phytometers, as well as in the vegetation in the field, indicated $\mathrm{N}$ limitation in these sites, which did not change after winter flooding. In this case, winter flooding must have weakened $\mathrm{N}$ limitation, resulting in an increased biomass of the vegetation. We have shown a shift from high $\mathrm{NO}_{3}$ to high $\mathrm{NH}_{4}$ availability in the pore water after winter flooding. Apparently, $L$. salicaria plants can use both forms of inorganic $\mathrm{N}$ directly for growth. Lythrum salicaria showed also higher biomass growth after winter flooding in the former agricultural site, which was K-limited. This suggests that $\mathrm{K}$ became more available for the plants, which was confirmed by the lower pore water $\mathrm{K}$ concentrations after the growth period in the winter-flooded cores. Summarizing, we conclude that the winter flooding causes higher availabilities of $\mathrm{N}$ in the agricultural
BGD

5, 5203-5232, 2008

\section{Plant site conditions} after winter flooding

V. Beumer et al.

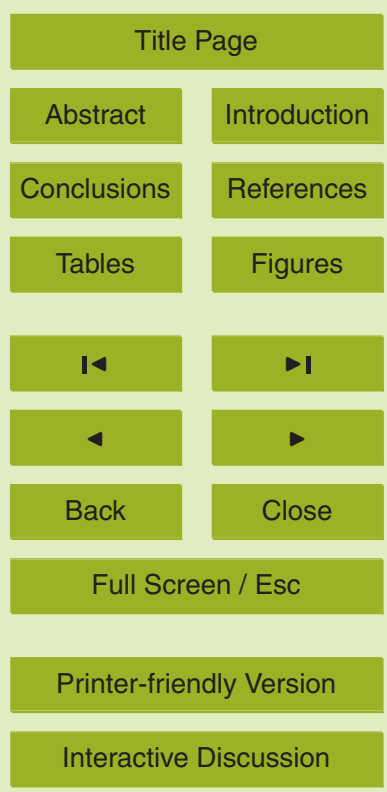

Interactive Discussion 
sites and $\mathrm{K}$ in the former agricultural site, because L. salicaria grew more biomass after winter flooding and indicated no change in type of nutrient limitation. Obviously, $A$. odoratum did not benefit from these conditions and must have experienced other types of effects.

\section{$5 \quad 4.2$ Toxicity}

The hampered growth of $A$. odoratum could have been the result of toxicity effects of iron or ammonium. Iron toxicity thresholds for iron sensitive plants starts from $8 \mathrm{mg} \cdot \mathrm{I}^{-1}$ (Snowden and Wheeler, 1993) and this concentration was well exceeded in our agricultural soils after winter flooding. However, the growth of $A$. odoratum was not hampered in the winter-flooded cores of the FA site, despite the high pore water Fe concentration, so that we can rule out toxic iron effects in our experiment. Anthoxantum odoratum has been reported to be rather sensitive to enhanced ammonium concentrations, although no quantitative information on toxic levels was given (Weeda et al., 1994). There is such information for species occurring in the same habitats with $A$. odoratum. Lucassen et al. (2003) found that Cirsium dissectum was negatively affected when pore water ammonium concentrations exceeded $3.5 \mathrm{mg} \cdot \mathrm{l}^{-1}$, while Van den Berg et al. (2005) found Succisa pratensis already negatively affected at $1.4 \mathrm{mg} \cdot \mathrm{I}^{-1}$. In our experiment, the ammonium concentrations in the agricultural sites and in the semi-natural land use group ranged between 3 and $19 \mathrm{mg} \cdot \mathrm{I}^{-1}$ during the first three weeks after the winter-flooded treatment. Therefore, it is likely that $A$. odoratum growth was affected by ammonium toxicity in these sites.

Several studies (Stevens et al., 1997; Lempe et al., 2001) have shown that L. salicaria is well suited to grow in anaerobic soil conditions. Also, Snowder and Wheeler (1993) found in growth experiments that $L$. salicaria was semi-tolerant for Fe, 25 it did not experience serious growth restrictions up to $50 \mathrm{mg} \cdot \mathrm{I}^{-1}$. We think that tolerance for high Fe concentrations is one of the factors explaining why $L$. salicaria was not negatively affected by the flooding treatment. Moreover, in the winter-flooded treatment the pore water Al concentration was lowered from potentially toxic levels to non-toxic levels,

BGD

5, 5203-5232, 2008

\section{Plant site conditions} after winter flooding

V. Beumer et al.



Interactive Discussion 
which could also have contributed to a better growth of $L$. salicaria in the flooded treatment. Toxic levels of Al for wetland species have hardly been reported, but Gensemer and Playle (1999) stated that rice seedlings were already growth inhibited at Al concentrations of $0.2 \mathrm{mg} \cdot \mathrm{I}^{-1}$, indicating that Al in the control cores of the ASN site may well 5 have been toxic ( $2 \mathrm{mg} \cdot \mathrm{I}^{-1}$ and higher) for our wetland species. The temporary lowering of the pore water Al concentration after the winter flood event probably allowed L. salicaria to survive, whereas the high Al concentrations in the non-flooded treatment are the most probably cause of the high mortality we found in this treatment.

\subsection{Differences in land use}

10 The phytometer experiment showed that, for soils that had not been subject to a winter flood, growth conditions for $A$. odoratum and $L$. salicaria were better suited in soils with agricultural than with semi-natural land use. The $A$. odoratum phytometers indicated a $P$ limitation in both semi-natural sites, while the plant nutrient concentrations in the field revealed an $\mathrm{N}$ limitation. This shows that plant nutrient limitation in the field not 5 always corresponds with that found in a phytometer experiment. Depending on the species composition in the field and the identity of the phytometers, results may or may not be similar. Both phytometers showed that winter flooding affected plant growth conditions most in the soils with agricultural land use. Lythrum salicaria showed that more nitrogen or potassium became available after winter flooding in the agricultural 20 land use group, while it did not show a change in nutrient availability in the semi-natural land use group. And $A$. odoratum indicated an increase of the availability of toxic compounds after winter flooding in the semi-natural land use group and, presumably, in the two agricultural sites; however, it did not indicate an increase in the availability of toxic compounds in the former agricultural site.
BGD

$5,5203-5232,2008$

\section{Plant site conditions after winter flooding}

V. Beumer et al.

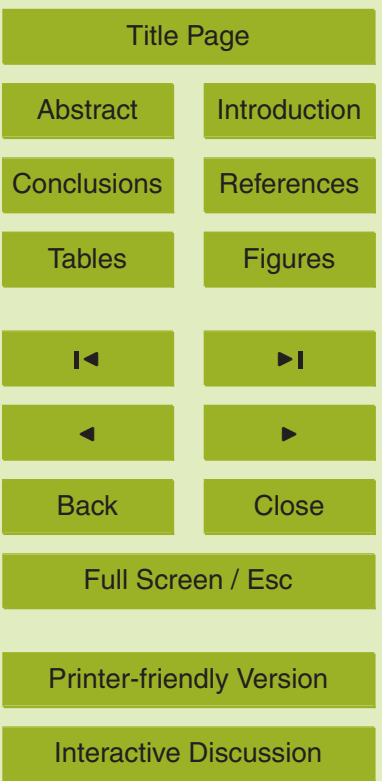




\subsection{Phytometer setup}

The results of the phytometer experiment showed that, even for cores from the same site, growth conditions after the winter-flooded treatment were experienced differently by our two plant species. This raises the question whether we can use a phytometer 5 setup to properly evaluate flooding effects on plant growth conditions. We argue that the answer is positive, for the following three reasons. First, the phytometer approach gave us a conclusive answer whether the combined reaction of various geochemical factors to winter flooding resulted in better or worse conditions for the growth of two contrasting floodplain species. Second, the approach allowed us to distinguish between nutritious and toxic effects by carefully comparing growth responses and stoichiometric characteristics of the nutrients in plant tissues. Of our two species, Anthoxanthum odoratum primarily reacted to the presence of growth-inhibiting compounds such as $\mathrm{Fe}, \mathrm{Al}$ and $\mathrm{NH}_{4}$, whereas Lythrum salicaria reacted to increased nutrient availability with a growth response. The use of these two species in combination has clear ad-

15 vantages, because $L$. salicaria is a species of nutrient-rich wetlands, obviously able to cope with anaerobic soil conditions and not hampered easily by potentially toxic compounds (Lempe et al., 2001; Zedler and Kercher, 2004). Therefore, it is well-suited to assess the nutrient status in previously flooded soils. Anthoxanthum odoratum is a species of humid, mesotrophic grasslands and less frequently found in wetlands with strongly fluctuating water tables (Weeda et al., 1994). It is probably less adapted to anaerobic soil conditions and will, therefore, be a better indicator of possible toxic effects as a result of flooding than $L$. salicaria. The combined use of these two species as phytometers has been shown to be appropriate to assess effects of winter flooding. Finally, we were able to detect different responses of the phytometers to flooding of soils with different land use histories. Both nutrient and toxicant availabilities were enhanced after winter flooding in agricultural sites; here, soil $\mathrm{P}$ content was high and $\mathrm{NH}_{4}$ and $\mathrm{Fe}$ became increasingly available after flooding. Plant growth in the semi-natural sites was mainly restricted by nutrient limitation and this remained so after winter flooding.

BGD

5, 5203-5232, 2008

Plant site conditions after winter flooding

V. Beumer et al.

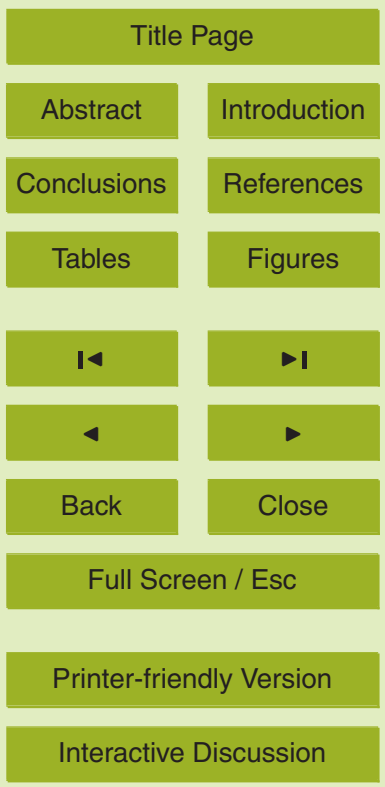

Interactive Discussion 
The potentially toxic Al concentration in the acidic semi-natural site was temporarily lowered after winter flooding. Here, the groundwater level was lower than in the other semi-natural sites, so, without flooding, the supply of basic cations might be low and the pore water Al concentration can reach high values. The results show that in stream 5 valley sites with disturbed hydrology, like our acid semi-natural site, unfavourable toxic growth conditions can be neutralised temporarily by winter flooding.

The phytometer approach is particularly suited to evaluate spring conditions after the flood has receded. Phytometers are seedlings that respond directly to extra nutrients and toxicants, because they have no below-ground rhizomes or storage organs with 10 a large perennial root system. In our experiment, they did not experience the actual winter flood with direct anaerobic conditions in the root zones and did not experience competition. This resulted in additional insights that cannot be obtained by measuring the response of the actual vegetation in the field. Another advantage is that the method can be used to predict flooding effects at sites which have not previously been subject to flooding. However, the limitation of the approach is that no direct conclusions can be drawn about the response of the vegetation in terms of changes in species composition. Moreover, different from the field situation, no sedimentation or erosion processes occurred in the phytometer experiment, although they have been reported to occur during winter flooding, with the associated nutrient enrichment caused by sedimentation (Kronvang et al., 2007). Our phytometer approach was designed to investigate winter flooding originating from groundwater exfiltration or rain water accumulation, without riverbank overflow. It involves two out of the four winter flooding situations (Beumer et al., 2008) that were recognized to be important to interpret flooding effects on geochemistry and vegetation in Dutch river valleys. Further comparisons of the response of phytometers with the response of the vegetation in the field, and incorporation of sedimentation and erosion effects, are the next steps for developing a phytometer approach as a robust, standardized methodology to evaluate the response of plant site conditions and vegetation composition to winter flooding.

\section{BGD}

5, 5203-5232, 2008

\section{Plant site conditions} after winter flooding

V. Beumer et al.



Interactive Discussion 


\section{References}

Beumer, V., van Wirdum, G., Beltman, B., Griffioen, J., and Verhoeven, J. T. A.: Geochemistry and flooding as determining factors of plant species composition in Dutch winter-flooded riverine grasslands, Sci. Total Environ., 402(1), 70-81, 2008.

5 Darke, A. K. and Walbridge, M. R.: Al and Fe biogeochemistry in a floodplain forest: Implications for $\mathrm{P}$ retention, Biogeochemistry, 51(1), 1-32, 2000.

Davies, M. S. and Snaydon, R. W.: Physiological differences among populations of Anthoxanthum odoratum L. collected from the Park Grass Experiment II., Response to aluminium, J. Appl. Ecol., 10, 47-55, 1973.

10 Gensemer, R. W. and Playle, R. C.: The Bioavailability and Toxicity of Aluminium in Aquatic Environments, Crit. Rev. Env. Sci. Tec., 29(4), 315-450, 1999.

Güsewell, S. and Koerselman, M.: Variation in nitrogen and phosphorus concentrations of wetland plants, Perspect. Plant Ecol., 5(1), 37-61, 2002.

Hogan, D. M., Jordan, T. E. and Walbridge, M. R.: Phosphorus retention and soil organic carbon in restored and natural freshwater wetlands, Wetlands, 24(3), 573-585, 2004.

Koerselman, W. and Meuleman, A. F. M.: The vegetation N:P ratio: A new tool to detect the nature of nutrient limitation, J. Appl. Ecol., 33(6), 1441-1450, 1996.

Kronvang, B., Andersen, I. K., Hoffmann, C. C., Pedersen, M. L., Ovesen, N. B., and Andersen, H. E.: Water exchange and deposition of sediment and phosphorus during inundation of natural and restored lowland floodplains, Water Air Soil Poll., 181(1-4), 115-121, 2007.

Lamers, L. P. M., Loeb, R., Antheunisse, A. M., Miletto, M., Lucassen, E. C. H. E. T., Boxman, A. W., Smolders, A. J. P., and Roelofs, J. G. M.: Biogeochemical constraints on the ecological rehabilitation of wetland vegetation in river floodplains, Hydrobiologia, 565, 165-186, 2007.

Lempe, J., Stevens, K. J., and Peterson, R. L.: Shoot responses of six Lythraceae species to flooding, Plant Biology, 3(2), 186-193, 2001.

Lucassen, E. C. H. E. T., Smolders, A. J. P., and Roelofs, J. G. M.: Increased groundwater levels cause iron toxicity in Glyceria fluitans (L.), Aquat. Bot., 66(4), 321-327, 2000.

Lucassen, E. C. H. E. T., Bobbink, R., Smolders, A. J. P., van der Ven, P. J. M., Lamers, L. P. M., and Roelofs, J. G. M.: Interactive effects of low $\mathrm{pH}$ and high ammonium levels responsible for the decline of Cirsium dissectum (L.), Hill, Plant Ecology, 165(1), 45-52, 2003.

Mitsch, W. J. and Gosselink, J. G.: Wetlands, 2nd Ed., Van Nostrand, Reinhold, New York, USA, 722 pp., 1993.
BGD

5, 5203-5232, 2008

\section{Plant site conditions after winter flooding}

V. Beumer et al.

Title Page

Abstract

Introduction

Conclusions

References

Tables

Figures

14

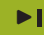

4

Back

Close

Full Screen / Esc

Printer-friendly Version

Interactive Discussion 
Olde Venterink, H., Pieterse, N. M., Belgers, J. D. M., Wassen, M. J., and de Ruiter, P. C.: N, P and $\mathrm{K}$ budgets along nutrient availability and productivity gradients in wetlands, Ecol. Appl., 12(4), 1010-1026, 2002.

Olde Venterink, H., Wassen, M. J., Verkroost, A. W. M., and de Ruiter, P. C.: Species richness5 productivity patterns differ between $\mathrm{N}-, \mathrm{P}-$, and K-limited wetlands, Ecology, 84(8), 21912199, 2003.

Page, A. L., Miller, R. H., and Keen D. R.: Methods of Soil Analysis, part 2, 2nd Ed., American Society of Agronomy and Soil Science Society of America, Madison, 1159 pp., 1982.

Ponnamperuma, F. N.: The chemistry of submerged soils, Adv. Agron., 24, 29-96, 1972.

10 Reddy, K. R. and Patrick, Jr., W. H.: Nitrogen transformations and loss in flooded soils and sediments, Crit. Rev. Env. Contr., 13, 273-309, 1984.

Roden, E. E. and Edmonds, J. W.: Phosphate mobilization in iron-rich anaerobic sediments: Microbial Fe(III) oxide reduction versus iron-sulfide formation, Arch. Hydrobiol., 139(3), 347378, 1997.

Snowden, R. E. D. and Wheeler, B. D.: Iron toxicity to fen plant-species, J. Ecol., 81(1), 35-46, 1993.

Stevens, K. J., Peterson, R. L., and Stephenson, G. R.: Morphological and anatomical responses of Lythrum salicaria $L$ (purple loosestrife) to an imposed water gradient, Int. J. Plant Sci., 158(2), 172-183, 1997.

van den Berg, L. J. L., Dorland, E., Vergeer, P., Hart, M. A. C., Bobbink, R., and Roelofs, J. G. M.: Decline of acid-sensitive plant species in heathland can be attributed to ammonium toxicity in combination with low pH, New Phytol., 166(2), 551-564, 2005.

Weeda, E. J., Westra, R., Westra, C., and Westra, T.: Nederlandse Ecologische Flora, Wilde planten en hun relaties, deel 2, IVN, Amsterdam, 1987.

Weeda, E. J., Westra, R., Westra, C., and Westra, T.: Nederlandse Oecologische Flora-Wilde planten en hun relaties, deel 5, IVN, Amsterdam, The Netherlands, 400 pp., 1994.

Wheeler, B. D., Shaw, S. C., and Cook, R. E. D.: Phytometric assessment of the fertility of undrained rich-fen soils, J. Appl. Ecol., 29(2), 466-475, 1992.

Zedler, J. B. and Kercher, S.: Causes and consequences of invasive plants in wetlands: Op-

\section{BGD}

5, 5203-5232, 2008

\section{Plant site conditions after winter flooding}

V. Beumer et al.

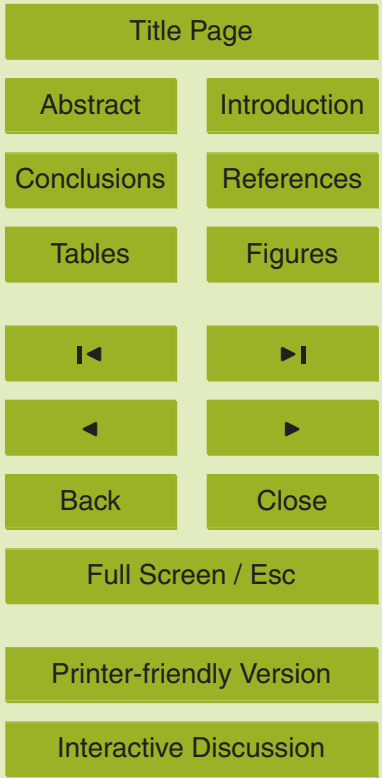




\section{BGD}

$5,5203-5232,2008$

\section{Plant site conditions after winter flooding}

Table 1. Characterization of the sites with respect to management, soil and plant (entire vegetation) nutrient concentration, indicated nutrient limitation and vegetation type.

\begin{tabular}{|c|c|c|c|c|c|c|c|c|c|c|c|c|c|c|}
\hline \multirow[b]{3}{*}{$\underline{\text { Sites }}$} & \multirow{3}{*}{ 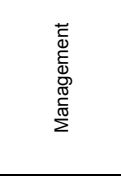 } & \multirow{3}{*}{ 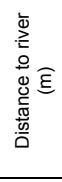 } & \multicolumn{7}{|c|}{ Top soil layer $(0-10 \mathrm{~cm}, \mathrm{n}=16$, August 2006$)$} & \multirow{2}{*}{\multicolumn{3}{|c|}{$\begin{array}{c}\text { Plant nutrient } \\
\text { concentrations }(\mathrm{mg} / \mathrm{g})\end{array}$}} & & \multirow[b]{3}{*}{ Vegetation type } \\
\hline & & & \multicolumn{2}{|c|}{ in \% weight } & \multicolumn{3}{|c|}{$\begin{array}{l}\text { Total soil nutrients } \\
\text { (mg/g dry soil) }\end{array}$} & \multicolumn{2}{|c|}{$\begin{array}{l}\text { Bio-available soil } \\
\text { nutrients ( } \mathrm{mg} / \mathrm{kg} \\
\text { dry soil) }\end{array}$} & & & & & \\
\hline & & & & है & $\mathrm{N}$ & $\mathrm{P}$ & $\mathrm{K}$ & $\mathrm{N}$ & $\mathrm{P}$ & $\mathrm{N}$ & $\mathrm{P}$ & K & & \\
\hline $\begin{array}{l}\text { Semi-natural } \\
\mathrm{I}\end{array}$ & Mowing & 102 & $\begin{array}{l}34 \\
\pm 3\end{array}$ & $\begin{array}{c}6.9 \\
\pm 0.8\end{array}$ & $\begin{array}{l}2.8 \\
\pm 0.8\end{array}$ & $\begin{array}{c}0.6 \\
\pm 0.2\end{array}$ & $\begin{array}{c}0.2 \\
\pm 0.1\end{array}$ & $\begin{array}{c}37 \\
\pm 19\end{array}$ & $\begin{array}{c}7.4 \\
\pm 2.4\end{array}$ & 18.8 & 1.8 & 14.0 & $\rightarrow \underset{\text { limitation }}{\mathrm{N}}$ & $\begin{array}{l}\text { Valeriano-Filipenduletum } \\
\text { holcetosum }\end{array}$ \\
\hline $\begin{array}{l}\text { Semi-natural } \\
\text { II }\end{array}$ & Mowing & 68 & $\begin{array}{l}46 \\
\pm 4\end{array}$ & $\begin{array}{r}11.5 \\
\pm 1.9\end{array}$ & $\begin{array}{c}4.8 \\
\pm 0.8\end{array}$ & $\begin{array}{c}0.9 \\
\pm 0.2\end{array}$ & $\begin{array}{c}0.2 \\
\pm 0.2\end{array}$ & $\begin{array}{r}14.2 \\
\pm 5.4\end{array}$ & $\begin{array}{l}5.7 \\
\pm 2.1\end{array}$ & 23.7 & 2.1 & 9.4 & $\rightarrow \quad \mathrm{N}$ & $\begin{array}{l}\text { Carex panicea-Succisa } \\
\text { pratensis }\end{array}$ \\
\hline $\begin{array}{l}\text { Acidic semi- } \\
\text { natural }\end{array}$ & Mowing & 223 & $\begin{array}{l}28 \\
\pm 3\end{array}$ & $\begin{array}{l}5.3 \\
\pm 1\end{array}$ & $\begin{array}{c}1.8 \\
\pm 0.9\end{array}$ & $\begin{array}{c}0.9 \\
\pm 0.2\end{array}$ & $\begin{array}{c}0.4 \\
\pm 0.1\end{array}$ & $\begin{array}{c}6.6 \\
\pm 9.2\end{array}$ & $\begin{array}{l}110 \\
\pm 31\end{array}$ & 21.6 & 2.7 & 5.9 & $\rightarrow \begin{aligned} \mathrm{N}+\mathrm{K} \text { co- } \\
\text { limitation }\end{aligned}$ & $\begin{array}{l}\mathrm{Sp} \text { : Agrostis capillaris, } \\
\text { Anthoxanthum odoratum }\end{array}$ \\
\hline $\begin{array}{l}\text { Former } \\
\text { agricultural }\end{array}$ & Grazing & 83 & $\begin{array}{l}27 \\
\pm 4\end{array}$ & $\begin{array}{c}5.7 \\
\pm 1.6\end{array}$ & $\begin{array}{c}2.6 \\
\pm 1.3\end{array}$ & $\begin{array}{c}1.5 \\
\pm 0.7\end{array}$ & $\begin{array}{c}0.3 \\
\pm 0.2\end{array}$ & $\begin{array}{c}4.7 \\
\pm 3.6\end{array}$ & $\begin{array}{c}68 \\
\pm 32\end{array}$ & 30.5 & 4.1 & 7.4 & $\rightarrow \underset{\text { limitation }}{\mathrm{K}}$ & $\begin{array}{l}\text { Ranunculo-Alopecuretum } \\
\text { equisetetosum palustris }\end{array}$ \\
\hline Agricultural I & $\begin{array}{l}\text { Grazing and } \\
\text { Fertilizing }\end{array}$ & 712 & $\begin{array}{l}21 \\
\pm 2\end{array}$ & $\begin{array}{c}3.8 \\
\pm 0.5\end{array}$ & $\begin{array}{c}1.4 \\
\pm 0.5\end{array}$ & $\begin{array}{l}1.7 \\
\pm 0.4\end{array}$ & $\begin{array}{c}0.5 \\
\pm 0.2\end{array}$ & $\begin{array}{c}2.1 \\
\pm 1.8\end{array}$ & $\begin{array}{l}400 \\
\pm 55\end{array}$ & 37.3 & 4.9 & 15.4 & $\rightarrow \underset{\text { limitation }}{\mathrm{N}}$ & $\begin{array}{l}\text { Plantagini-Lolietum perennis } \\
\text { typicum }\end{array}$ \\
\hline Agricultural II & $\begin{array}{l}\text { Grazing and } \\
\text { Fertilizing }\end{array}$ & 690 & $\begin{array}{l}25 \\
\pm 3\end{array}$ & $\begin{array}{c}3.3 \\
\pm 0.6\end{array}$ & $\begin{array}{c}1.1 \\
\pm 0.5\end{array}$ & $\begin{array}{l}1.4 \\
\pm 0.3\end{array}$ & $\begin{array}{c}0.3 \\
\pm 0.1\end{array}$ & $\begin{array}{c}4.0 \\
\pm 4.3\end{array}$ & $\begin{array}{l}287 \\
\pm 56\end{array}$ & 18.4 & 3.6 & 18.6 & $\begin{aligned} \rightarrow \mathrm{N} & \text { limitation }\end{aligned}$ & $\begin{array}{l}\text { Plantagini-Lolietum perennis } \\
\text { typicum }\end{array}$ \\
\hline
\end{tabular}

\section{Beumer et al.}

Title Page

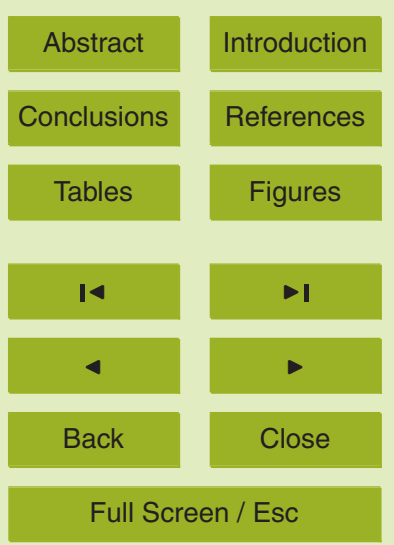

Printer-friendly Version

Interactive Discussion 


\section{BGD}

5, 5203-5232, 2008

\section{Plant site conditions after winter flooding}

Table 2. Survival of Anthoxantum odoratum and Lythrum salicaria on soil cores that had been subject to winter flooding and not $(n=8)$.

\section{Beumer et al.}

\begin{tabular}{lccc}
\hline Sites & Treatments & $\begin{array}{c}\text { Lythrum salicaria } \\
\text { Survival }(\%)(n=8)\end{array}$ & $\begin{array}{c}\text { Anthoxantum odoratum } \\
\text { Survival }(\%)(n=8)\end{array}$ \\
\hline Semi-natural I & Control & 75 & 75 \\
& Winter-flooded & 100 & 100 \\
Semi-natural II & Control & 100 & 100 \\
& Winter-flooded & 88 & 100 \\
Acidic Semi-natural & Control & 25 & 88 \\
& Winter-flooded & 100 & 100 \\
\hline Former Agricultural & Control & 100 & 88 \\
& Winter-flooded & 88 & 88 \\
Agricultural I & Control & 100 & 100 \\
& Winter-flooded & 100 & 100 \\
Agricultural II & Control & 100 & 88 \\
& Winter-flooded & 88 & 100
\end{tabular}

Title Page

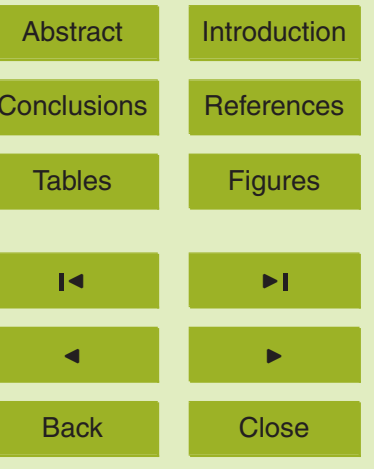

Full Screen / Esc

Printer-friendly Version

Interactive Discussion 
Table 3. The results of a two-way ANOVA for the biomass and nutrients of both phytometer species, with treatment and land use as fixed factors and site as nested factor in land use.

\begin{tabular}{|c|c|c|c|c|c|}
\hline & \multirow[b]{2}{*}{ Effect } & \multicolumn{2}{|c|}{ Anthoxantum odoratum } & \multicolumn{2}{|c|}{ Lythrum salicaria } \\
\hline & & Chi-Square & $p$ & Chi-Square & $p$ \\
\hline \multirow[t]{4}{*}{ Biomass } & Treatment & 7.8 & 0.005 & 6.8 & 0.009 \\
\hline & Land use & 31.5 & 0.000 & 331 & 0.000 \\
\hline & $T * \mathrm{~L}$ & 1.1 & 0.290 & 1.0 & 0.314 \\
\hline & Site (in L) & 34.6 & 0.000 & 17.0 & 0.002 \\
\hline \multirow[t]{4}{*}{$\mathrm{N}$} & Treatment & 2.9 & 0.089 & 1.2 & 0.265 \\
\hline & Land use & 51.4 & 0.000 & 3.0 & 0.083 \\
\hline & $T^{*} \mathrm{~L}$ & 3.5 & 0.063 & 2.1 & 0.151 \\
\hline & Site (in L) & 93.8 & 0.000 & 15.4 & 0.004 \\
\hline \multirow[t]{4}{*}{$\mathrm{P}$} & Treatment & 0.8 & 0.371 & 4.2 & 0.518 \\
\hline & Land use & 180 & 0.000 & 116 & 0.000 \\
\hline & $T^{*} \mathrm{~L}$ & 4.3 & 0.038 & 0.3 & 0.597 \\
\hline & Site (in L) & 37.3 & 0.000 & 30.6 & 0.000 \\
\hline \multirow[t]{4}{*}{ K } & Treatment & 52.1 & 0.000 & 2.8 & 0.092 \\
\hline & Land use & 8.4 & 0.004 & 26.0 & 0.000 \\
\hline & $T^{*} \mathrm{~L}$ & 7.4 & 0.005 & 1.7 & 0.189 \\
\hline & Site (in L) & 139 & 0.000 & 86.6 & 0.000 \\
\hline \multirow[t]{4}{*}{ Total N } & Treatment & 11.6 & 0.001 & 5.8 & 0.016 \\
\hline & Land use & 4.7 & 0.030 & 401 & 0.000 \\
\hline & $T * L$ & 0.2 & 0.624 & 0.4 & 0.533 \\
\hline & Site (in L) & 30.6 & 0.000 & 25.9 & 0.000 \\
\hline \multirow[t]{4}{*}{ Total P } & Treatment & 4.6 & 0.031 & 8.0 & 0.005 \\
\hline & Land use & 104 & 0.000 & 680 & 0.000 \\
\hline & $T^{*} \mathrm{~L}$ & 0.2 & 0.692 & 1.3 & 0.249 \\
\hline & Site (in L) & 54.8 & 0.000 & 37.3 & 0.000 \\
\hline \multirow[t]{4}{*}{ Total K } & Treatment & 0.5 & 0.474 & 21.6 & 0.000 \\
\hline & Land use & 31.6 & 0.000 & 333 & 0.000 \\
\hline & $T * L$ & 2.2 & 0.139 & 0.4 & 0.547 \\
\hline & Site (in L) & 26.6 & 0.000 & 35.1 & 0.000 \\
\hline \multirow[t]{4}{*}{$N: P$ ratio } & Treatment & 5.2 & 0.023 & 0.6 & 0.445 \\
\hline & Land use & 347 & 0.000 & 70.2 & 0.000 \\
\hline & $T^{*} \mathrm{~L}$ & 0.01 & 0.930 & 0.04 & 0.848 \\
\hline & Site (in L) & 148 & 0.000 & 97.3 & 0.000 \\
\hline \multirow[t]{4}{*}{$\mathrm{N}: \mathrm{K}$ ratio } & Treatment & 63.3 & 0.000 & 10.7 & 0.001 \\
\hline & Land use & 6.0 & 0.014 & 59.6 & 0.000 \\
\hline & $T * \mathrm{~L}$ & 1.7 & 0.187 & 0.2 & 0.627 \\
\hline & Site (in L) & 141 & 0.000 & 139 & 0.000 \\
\hline \multirow[t]{4}{*}{$\mathrm{P}: \mathrm{K}$ ratio } & Treatment & 43.9 & 0.000 & 7.0 & 0.008 \\
\hline & Land use & 147 & 0.000 & 231 & 0.000 \\
\hline & $T^{*} \mathrm{~L}$ & 1.1 & 0.373 & 1.5 & 0.226 \\
\hline & Site (in L) & 139 & 0.000 & 131 & 0.000 \\
\hline
\end{tabular}

BGD

5, 5203-5232, 2008

\section{Plant site conditions after winter flooding}

V. Beumer et al.

Title Page

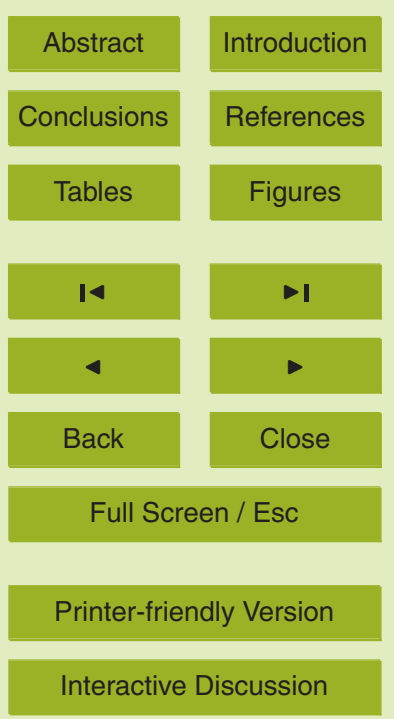


Table 4. Average concentrations of $\mathrm{NO}_{3}, \mathrm{NH}_{4}, \mathrm{PO}_{4}$ and $\mathrm{K}$ in the pore water sampled during the phytometer growth experiment at day 3,17 and 57. Results of a two-way ANOVA for the concentrations at day 3 with land use and treatment as fixed factors are shown, as well as two-way ANOVA's with time and treatment as fixed factors for both land use groups separately. NS (not significant) $=p>0.05$.

\begin{tabular}{|c|c|c|c|c|c|c|c|c|c|c|c|c|c|}
\hline & & \multicolumn{3}{|c|}{$\mathrm{NO}_{3}\left(\mathrm{mg} \cdot \mathrm{l}^{-1}\right)$} & \multicolumn{3}{|c|}{$\mathrm{NH}_{4}\left(\mathrm{mg} \cdot \mathrm{l}^{-1}\right)$} & \multicolumn{3}{|c|}{$\mathrm{PO}_{4}\left(\mathrm{mg} \cdot \mathrm{l}^{-1}\right)$} & \multicolumn{3}{|c|}{$\mathrm{K}\left(\mathrm{mg} \cdot \mathrm{I}^{-1}\right)$} \\
\hline \multicolumn{2}{|c|}{ During phytometer growth: day } & 3 & 17 & 57 & 3 & 17 & 57 & 3 & 17 & 57 & 3 & 17 & 57 \\
\hline Semi-natural I & Control & 1.3 & 0.2 & 0.2 & 3.2 & 5.3 & 6.1 & 0.2 & 0.0 & 0.0 & 20 & 8.5 & 1.1 \\
\hline \multirow[t]{2}{*}{ Semi-natural II } & Control & 0.5 & 0.0 & 0.2 & 1.0 & 0.9 & 4.0 & 0.3 & 0.0 & 0.0 & 9.8 & 3.5 & 1.8 \\
\hline & Flooded & 8.9 & 0.5 & 0.2 & 3.1 & 1.4 & 1.9 & 0.3 & 0.1 & 0.0 & 13 & 2.8 & 5.2 \\
\hline Acidic Semi-natural & Control & 115 & 40 & 2.1 & 0.3 & 0.5 & 1.4 & 0.1 & 0.0 & 0.0 & 1.1 & 1.6 & 2.9 \\
\hline Former Agricultural & Flooded & 0.2 & 1.1 & 0.6 & 9.9 & 5.2 & 1.5 & 0.1 & 0.0 & 0.0 & 9.3 & 1.8 & 1.6 \\
\hline \multirow[t]{2}{*}{ Agricultural I } & Control & 175 & 0.9 & 0.5 & 0.6 & 0.9 & 2.0 & 0.2 & 0.4 & 0.2 & 17 & 18 & 13 \\
\hline & Flooded & 0.5 & 0.3 & 0.9 & 4.5 & 4.0 & 2.3 & 0.3 & 0.1 & 0.2 & 17 & 7.0 & 7.3 \\
\hline \multirow[t]{2}{*}{ Agricultural II } & Control & 5.0 & 0.3 & 0.1 & 1.5 & 2.5 & 5.4 & 0.4 & 0.2 & 0.1 & 4.7 & 7.7 & 17 \\
\hline & Flooded & 0.0 & 0.2 & 0.1 & 19 & 8.5 & 6.3 & 0.2 & 0.5 & 0.1 & 50 & 12 & 13 \\
\hline \multirow[t]{2}{*}{ Semi-natural sites } & Treatment effect $(\mathrm{T})$ & \multicolumn{3}{|c|}{ NS } & \multirow{2}{*}{\multicolumn{3}{|c|}{$\begin{array}{l}\mathrm{P}=0.000 \text { and } F=18 \\
\mathrm{P}=0.042 \text { and } F=3.6\end{array}$}} & \multicolumn{3}{|c|}{ NS } & & .021 & $F=6.0$ \\
\hline & $\mathrm{Ti}^{\star} \mathrm{T}$ interaction & & NS & & & & & & & & & & \\
\hline & Time effect (Ti) & $\mathrm{P}=0$. & 023 a & $F=4.3$ & & & & & & & & & \\
\hline Agricultural sites & Treatment effect $(\mathrm{T})$ & $P=0$ & 006 a & $F=8.8$ & $\mathrm{P}=\mathrm{C}$ & .035 & $F=4.9$ & & $\mathrm{~N}$ & & & & \\
\hline & $\mathrm{Ti}^{\star} \mathrm{T}$ interaction & $P=0$ & 022 a & $F=4.4$ & $P=C$ & .027 & $F=4.1$ & & $\mathrm{~N}$ & & & & \\
\hline
\end{tabular}

\section{$5,5203-5232,2008$}

\section{Plant site conditions after winter flooding}

\section{Beumer et al.}

Title Page

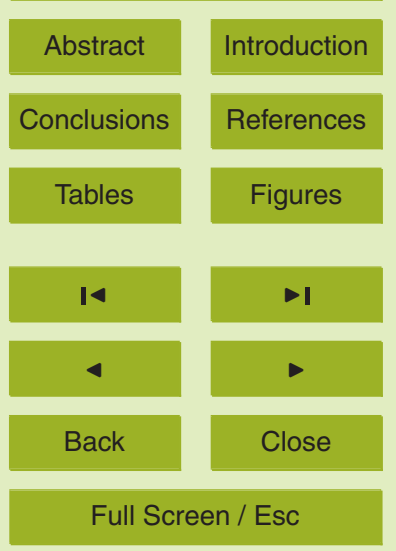

Printer-friendly Version

Interactive Discussion 
Table 5. Average concentrations of $\mathrm{Al}, \mathrm{Fe}$ and $\mathrm{Ca}$ in, and average $\mathrm{pH}$ of, the pore water sampled during the phytometer growth experiment at day 3,17 and 57. Results of a two-way ANOVA for the concentrations at day 3 with land use and treatment as fixed factors are shown, as well as two-way ANOVA's with time and treatment as fixed factors for both land use groups separately. NS (not significant) $=p>0.05$.

\begin{tabular}{|c|c|c|c|c|c|c|c|c|c|c|c|c|c|}
\hline & & \multicolumn{3}{|c|}{$\mathrm{pH}$} & \multicolumn{3}{|c|}{$\mathrm{Al}\left(\mathrm{mg} \cdot \mathrm{I}^{-1}\right)$} & \multicolumn{3}{|c|}{$\mathrm{Fe}\left(\mathrm{mg} \cdot \mathrm{I}^{-1}\right)$} & \multicolumn{3}{|c|}{$\mathrm{Ca}\left(\left.\mathrm{mg} \cdot\right|^{-1}\right)$} \\
\hline \multicolumn{2}{|c|}{ During phytometer growth: day } & 3 & 17 & 57 & 3 & 17 & 57 & 3 & 17 & 57 & 3 & 17 & 57 \\
\hline \multirow{2}{*}{ Semi-natural I } & Control & 5.9 & 5.9 & 5.3 & 0.0 & 0.1 & 0.3 & 0.7 & 0.7 & 1.8 & 8.6 & 16 & 38 \\
\hline & Flooded & 6.1 & 5.6 & 4.3 & 0.1 & 0.0 & 0.6 & 11 & - & - & 30 & 20 & 50 \\
\hline \multirow[t]{2}{*}{ Semi-natural II } & Control & 5.8 & 4.9 & 5.0 & 0.0 & 0.1 & 0.4 & 0.9 & 2.0 & 7.2 & 13 & 15 & 32 \\
\hline & Flooded & 6.1 & 5.2 & 5.4 & 0.0 & 0.2 & 0.2 & - & 2.8 & 1.2 & 35 & 19 & 35 \\
\hline \multirow{2}{*}{ Acidic Semi-natural } & Control & 3.9 & 4.0 & 4.1 & 2.1 & 3.4 & 2.7 & 0.3 & 0.5 & 5.1 & 7.9 & 6.6 & 6.7 \\
\hline & Flooded & 4.7 & 4.6 & 4.4 & 0.2 & 0.7 & 1.6 & 4.5 & 5.0 & 8.4 & 5.9 & 7.4 & 14 \\
\hline \multirow[t]{2}{*}{ Former Agricultural } & Control & 5.2 & 5.3 & 5.7 & 0.0 & 0.1 & 0.1 & 0.7 & 0.5 & 1.7 & 64 & 41 & 49 \\
\hline & Flooded & 6.1 & 6.4 & 6.5 & 0.0 & 0.0 & 0.1 & 21 & 6.4 & 14 & 31 & 36 & 53 \\
\hline \multirow[t]{2}{*}{ Agricultural I } & Control & 6.1 & 6.4 & 6.5 & 0.0 & 0.0 & 0.0 & 0.4 & 0.8 & 2.8 & 52 & 60 & 62 \\
\hline & Flooded & 7.0 & 7.0 & 6.8 & 0.0 & 0.1 & 0.1 & 12 & 22 & 10 & 51 & 68 & 95 \\
\hline \multirow[t]{2}{*}{ Agricultural II } & Control & 5.7 & 5.9 & 5.7 & 0.0 & 0.1 & 0.2 & 1.8 & 5.2 & 17 & 18 & 25 & 44 \\
\hline & Flooded & 5.2 & 6.5 & 6.2 & 0.8 & 0.3 & 0.5 & 63 & 13 & 19 & 69 & 26 & 54 \\
\hline \multirow{3}{*}{ Day 3} & Land use effect (L) & \multicolumn{3}{|c|}{$\mathrm{P}=0.031$ and $F=5.4$} & \multicolumn{3}{|c|}{$\mathrm{P}=0.037$ and $F=5.0$} & \multirow{3}{*}{\multicolumn{3}{|c|}{$\begin{array}{c}\mathrm{NS} \\
\mathrm{P}=0.000 \text { and } F=83 \\
\mathrm{NS}\end{array}$}} & \multirow{3}{*}{\multicolumn{3}{|c|}{$\begin{array}{c}\mathrm{P}=0.000 \text { and } F=40 \\
\mathrm{NS} \\
\mathrm{NS}\end{array}$}} \\
\hline & Treatment effect (T) & & & & & & & & & & & & \\
\hline & $\mathrm{L}^{*} \mathrm{~T}$ interaction & \multicolumn{3}{|c|}{ NS } & \multicolumn{3}{|c|}{ NS } & & & & & & \\
\hline \multirow{3}{*}{ Semi-natural sites } & Time effect (Ti) & \multicolumn{3}{|c|}{ NS } & \multirow{2}{*}{\multicolumn{3}{|c|}{ NS }} & \multirow{3}{*}{\multicolumn{3}{|c|}{$\begin{array}{c}\mathrm{NS} \\
\mathrm{P}=0.000 \text { and } F=19 \\
\mathrm{NS}\end{array}$}} & \multicolumn{3}{|c|}{$\mathrm{P}=0.008$ and $F=5.3$} \\
\hline & Treatment effect $(T)$ & \multirow{2}{*}{\multicolumn{3}{|c|}{$\begin{array}{l}\text { NS } \\
\text { NS }\end{array}$}} & \multicolumn{2}{|c|}{ NS } & & & & & \\
\hline & $\mathrm{Ti}^{\star} \mathrm{Tr}$ interaction & & & & & $\mathrm{N}$ & & & & & \multicolumn{3}{|c|}{ NS } \\
\hline \multirow{3}{*}{ Agricultural sites } & Time effect (Ti) & \multicolumn{3}{|c|}{ NS } & \multicolumn{3}{|c|}{ NS } & & $\mathrm{N}$ & & $\mathrm{P}=0$ & 031 & $F=3.7$ \\
\hline & Treatment effect $(T)$ & & & & & $\mathrm{N}$ & & $\mathrm{P}=0$ & $.000 \mathrm{a}$ & $F=19$ & & & \\
\hline & $\mathrm{Ti}^{\star} \mathrm{T}$ interaction & & & & & $\mathrm{N}$ & & & $\mathrm{N}$ & & & & \\
\hline
\end{tabular}

\section{$5,5203-5232,2008$}

\section{Plant site conditions after winter flooding}

\section{Beumer et al.}

Title Page

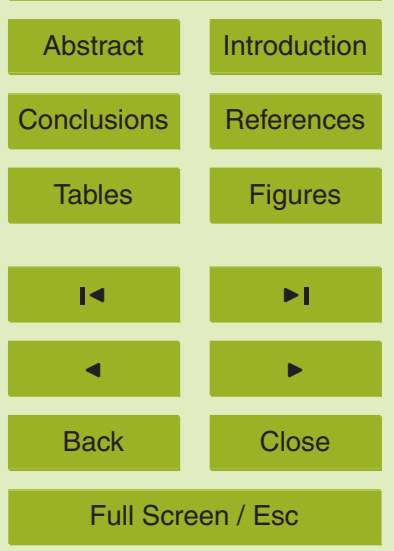

Printer-friendly Version

Interactive Discussion 


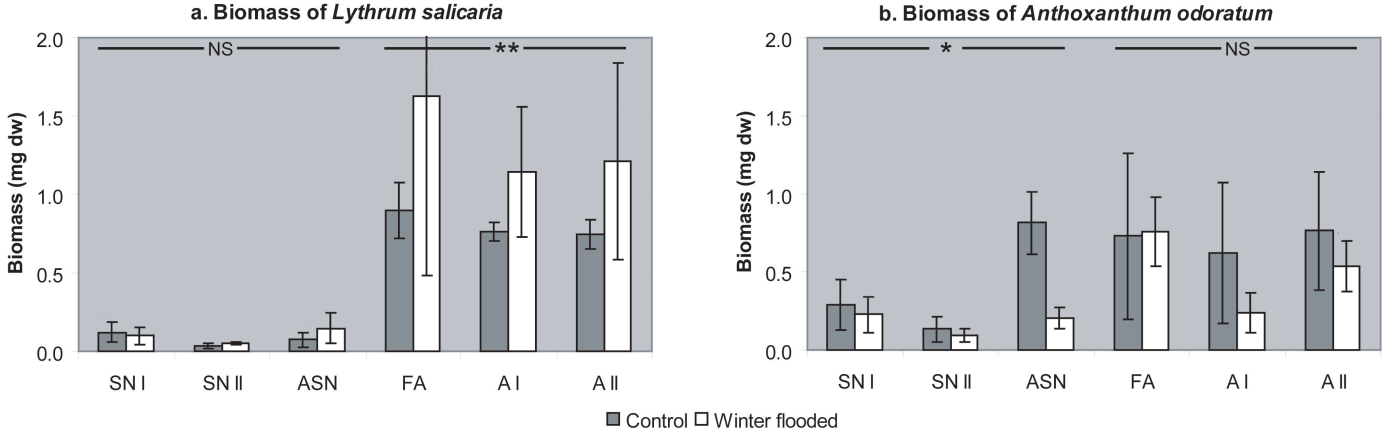

Fig. 1. The biomass of Anthoxantum odoratum (a) and Lythrum salicaria (b) phytometers in the control (dark bars) and the winter-flooded treatment (light bars) after 8 weeks of growth on soil cores from 6 sites (SNI=Semi-natural II, SNII=Semi-natural II, ASN=Acidic Semi-natural, $\mathrm{FA}=$ Former Agricultural, $\mathrm{Al}=$ Agricultural I and All=Agricultural II). At the top of the graphs the significance of the treatment effect per land use is indicated (NS=Not Significant, ${ }^{*}=p<0.05$ and ${ }^{* *}=p<0.01$.

\section{Plant site conditions after winter flooding}

V. Beumer et al.

Title Page



Full Screen / Esc

Printer-friendly Version

Interactive Discussion 
BGD

5, 5203-5232, 2008

\section{Plant site conditions after winter flooding}

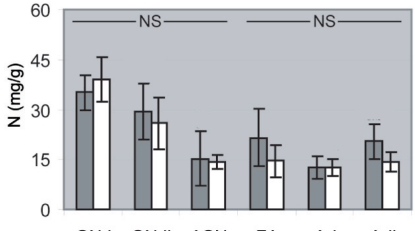

b. P concentration

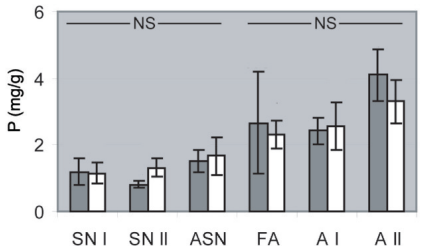

e. Total P content

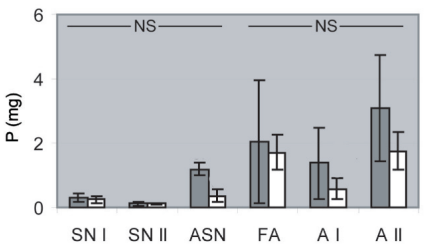

c. $\mathrm{K}$ concentration

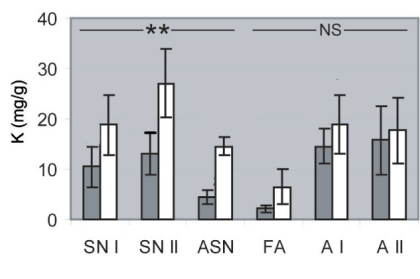

f. Total $\mathrm{K}$ content

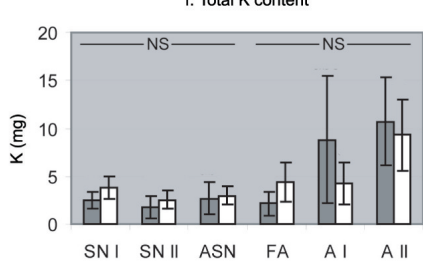

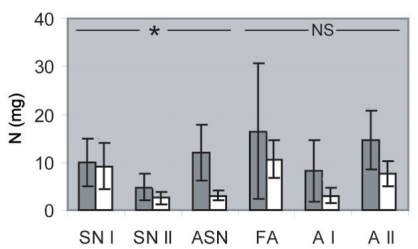

Fig. 2. The concentrations and contents of $\mathrm{N}, \mathrm{P}$ and $\mathrm{K}$ of Anthoxantum odoratum in the control (dark bars) and the winter-flooded treatment (light bars) after 8 weeks of growth on soil cores from 6 sites (SNI=Semi-natural II, SNII=Semi-natural II, ASN=Acidic Semi-natural, FA=Former Agricultural, $\mathrm{Al}=$ Agricultural $\mathrm{I}$ and $\mathrm{All}=$ Agricultural II). At the top of the graphs the significance of the treatment effect per land use is indicated (NS=Not Significant, ${ }^{*}=p<0.05$ and ${ }^{* *}=p<0.01$ ).
V. Beumer et al.

Title Page

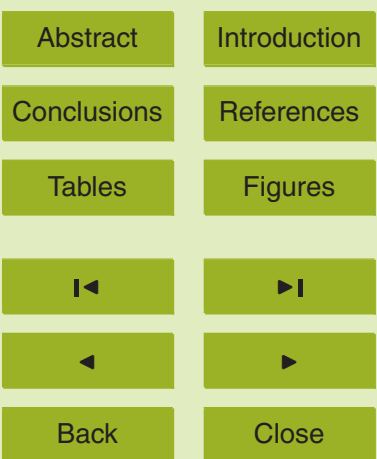

Full Screen / Esc

Printer-friendly Version

Interactive Discussion 
BGD

5, 5203-5232, 2008

\section{Plant site conditions} after winter flooding
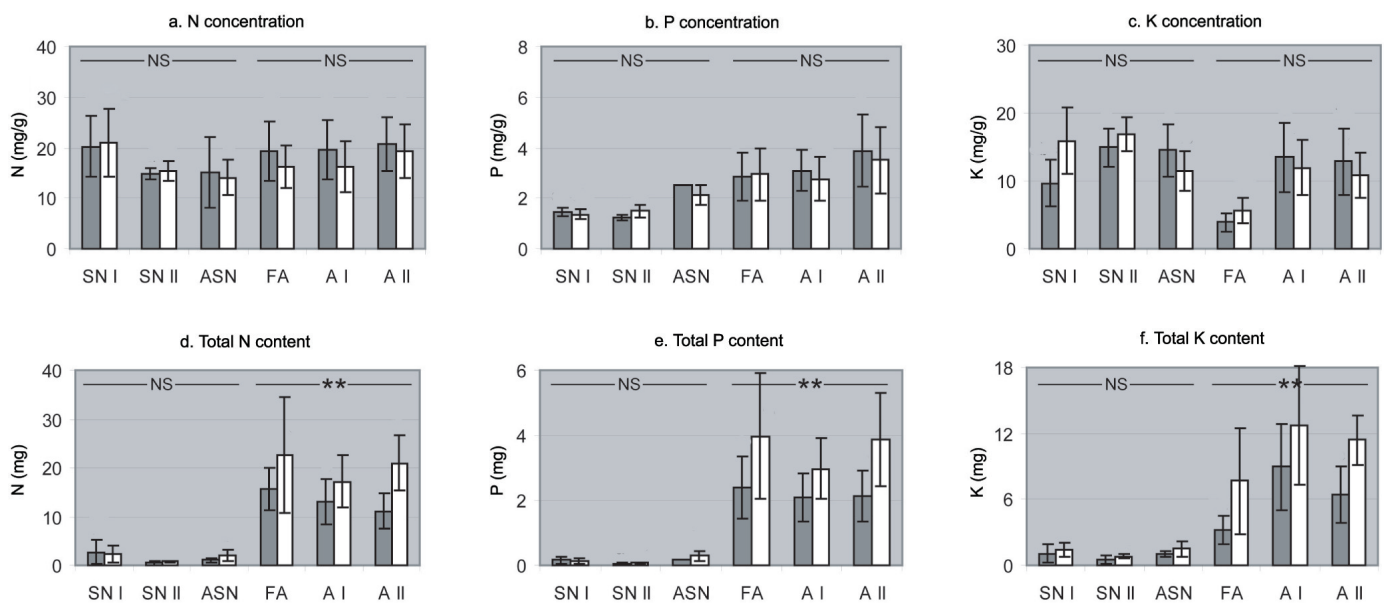

Fig. 3. The concentrations and contents of $\mathrm{N}, \mathrm{P}$ and $\mathrm{K}$ of Lythrum salicaria in the control (dark bars) and the winter-flooded treatment (light bars) after 8 weeks of growth on soil cores from 6 sites (SNI=Semi-natural II, SNII=Semi-natural II, ASN=Acidic Semi-natural, FA=Former Agricultural, $\mathrm{Al}=$ Agricultural $\mathrm{I}$ and $\mathrm{All}=$ Agricultural II). At the top of the graphs the significance of the treatment effect per land use is indicated (NS $=$ Not Significant, ${ }^{*}=p<0.05$ and ${ }^{* *}=p<0.01$ ).

\section{Beumer et al.}

Title Page

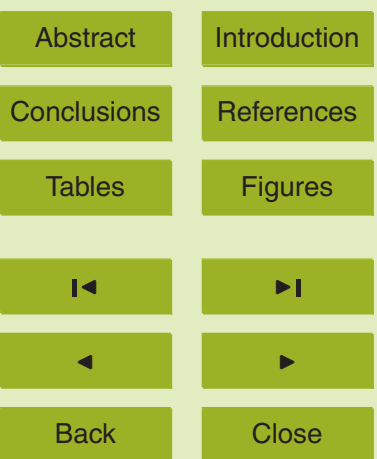

Full Screen / Esc

Printer-friendly Version

Interactive Discussion 
Plant nutrient ratios $\square$ Control $\square$ Winter flooded
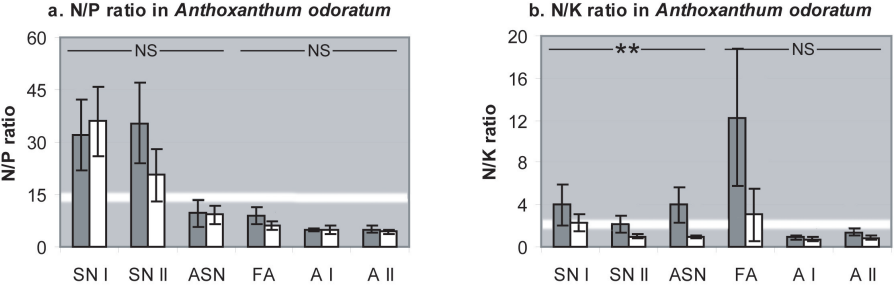

d. N/P ratio in Lythrum salicaria

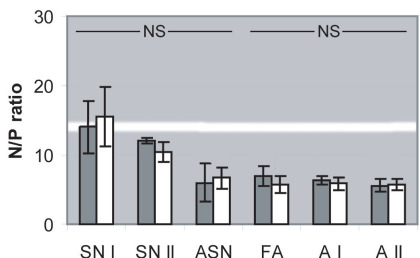

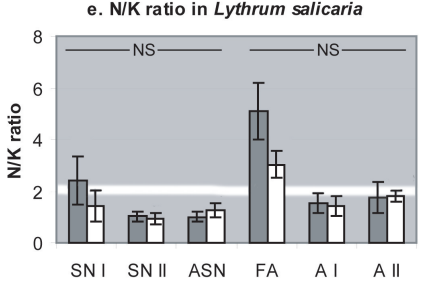

$\mathrm{P} / \mathrm{K}$ ratio in Anthoxanthum odoratum

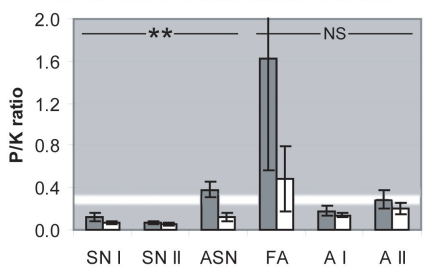

f. P/K ratio in Lythrum salicaria



5, 5203-5232, 2008

Plant site conditions after winter flooding

V. Beumer et al.

Title Page

Abstract

Conclusions

Tables



Back
Introduction

References

Figures

$\rightarrow 1$



Close

Full Screen / Esc

Printer-friendly Version

Interactive Discussion 